\title{
TCOM \\ COVID-19 crisis memes, rhetorical arena theory and multimodality
}

\section{Rick Pulos}

Abstract

Keywords

DOI
On February 11, 2020, the World Health Organization announced the name of a new disease, COVID-19. As the virus that causes the disease spread across the globe, the world went into crisis mode. The various actors of the COVID-19 crisis include, in part, politicians, scientists, health experts, citizens, journalists, front line workers, first responders, organizations, and so on. Their voices and their related communicative processes play out in the rhetorical arena that emerges from the crisis. Crisis memes are a particularly intriguing and salient part of the COVID-19 public discourse. Combining the theoretical implications of rhetorical arena theory (RAT) with multimodality and its close ties to social semiotics, this paper will analyze the unique nature of memes created during the cycle of a crisis.

Public understanding of science and technology; Science and media; Visual communication

https://doi.org/10.22323/2.19070201

Submitted: 27th June 2020

Accepted: 11th September 2020

Published: 14th December 2020

On February 11, 2020, the World Health Organization announced the name of a new disease, COVID-19. As the virus that causes the disease spread across the globe, the world went into crisis mode. COVID-19 is now a household name across the planet and the speed and level of its rise to this status in public discourse is undeniable. The crisis has led to government lockdowns, economic disaster, panic buying, political peacocking, protests and, sadly, illness and death. Specific to the COVID-19 crisis is a slew of terms, including anacronyms, that have entered into the lexicon of popular culture related to and shaped by the response to the crisis. Social distancing, PPE (personal protective equipment), N95 respirators, flattening the curve, self-quarantine, essential businesses, frontline workers, herd immunity, and so forth. These terms are not something the average citizen could have sourced or would have used prior to the response to the crisis. Many of these terms were introduced to the public via the media by various actors during the unfolding of the crisis including government officials, health professionals and science experts.

By the very nature of the COVID-19 crisis as a public health issue, governments around the globe were forced into crisis mode. Crisis communication is a growing 
field and Heath [2010] declares that "part of that interest comes from the fact that crisis is dramatic; it is newsworthy" (p. 1). Not since 9/11 has any topic been so newsworthy and dramatic on a global scale like COVID-19. The United States declared a national emergency on March 13, 2020 and immediately moved to reduce the spread of the virus that causes COVID-19. Frandsen and Johansen [2010] suggest that once a crisis erupts, a rhetorical arena materializes where all the stakeholders, or actors, create a complex and dynamic system of voices. The various actors of the COVID-19 crisis include, in part, politicians, citizens, journalists, health and science experts, front line workers, first responders, organizations, foreign countries and so on. Their voices and the communicative process that plays out in the rhetorical arena shapes and influences the discourse community of the COVID-19 crisis [Frandsen and Johansen, 2010]. Combining the theoretical implications of rhetorical arena theory (RAT) with multimodality and its close ties to social semiotics will allow for a deep interpretation of crisis memes.

Crisis memes are a particularly intriguing and salient part of the COVID-19 public discourse. They perpetuate the newness and the popularity of the terminology and information delivered by government officials, corporations, the media, scientists, doctors, and other actors. They also add to the public conversation about the crisis by making commentary in a participatory manner, sometimes seriously and sometimes by joking or through sarcasm. Memes are cultural and social artifacts [Milner, 2012] that have great potential for making meaning in a discourse community. Crisis memes operate differently than memes generated during normal situations because they are created within an arena specifically tied to a unique crisis. Once these crisis memes are created, tweeted, posted, distributed, Facebooked, et cetera, they can only be decoded contextually by relating each back to the arena in which they were generated. This paper will look at a variety of crisis memes generated as a result of COVID-19 by analyzing the multimodal nature of memes and breaking them down into individual modes. Analysis and interpretation of the individual modes will reveal that the pandemic itself is the dominant mode in crisis meme meaning-making and that other modes are subservient to that dominance. Breaking down a crisis meme to its modal parts will show the complexity of the intertextuality of the multimodal system at play and reveal attitudes, opinions and thoughts about the COVID-19 crisis.

\section{Memes}

Scrolling through Facebook or twitter most of us have had a chuckle or two at a meme a friend shared. Memes have this instant way of making commentary about life, sometimes through humor and sometimes with serious underpinnings. In the prevailing academic literature memes are discussed from a variety of perspectives. For example, White-Farnham [2019] looked at the grammar meme and its rhetorical power and Grundlingh [2018] argued that memes are effectively speech acts. Shifman [2012] notes that serious debates continue to rage over memes and memetics in the academy. This paper will take inspiration from scholars who have defined memes "as dynamic entities that spread in response to technological, cultural and social choices made by people [emphasis in original]" [Shifman, 2012, p. 189] and as a part of participatory culture where memes are seen "as artifacts [that] possess both cultural and social attributes as they are produced, reproduced, and transformed to reconstitute the social system" [Wiggins and Bowers, 2015, p. 1891]. Extending this notion of memes as artifacts, Milner [2012] suggests they are multimodal artifacts and he elucidates their significance by noting how "memes, 
like other 'everyday' texts, are important because social texts are the raw materials in the construction of societal discourses" (p. 11).

Milner [2012] also provides an extensive taxonomy of memes but cautions that it is difficult to categorize all the possible meme forms. The methodology section below lays out how the memes of this paper were found. Most of the memes discussed below are what Milner [2012] describes as macros:

Macros consist, predominantly, of a still image overlaid with text (though animated GIFs will also frequently receive the same treatment). The text is predominantly white and all caps; the font is predominantly Impact. (p. 89)

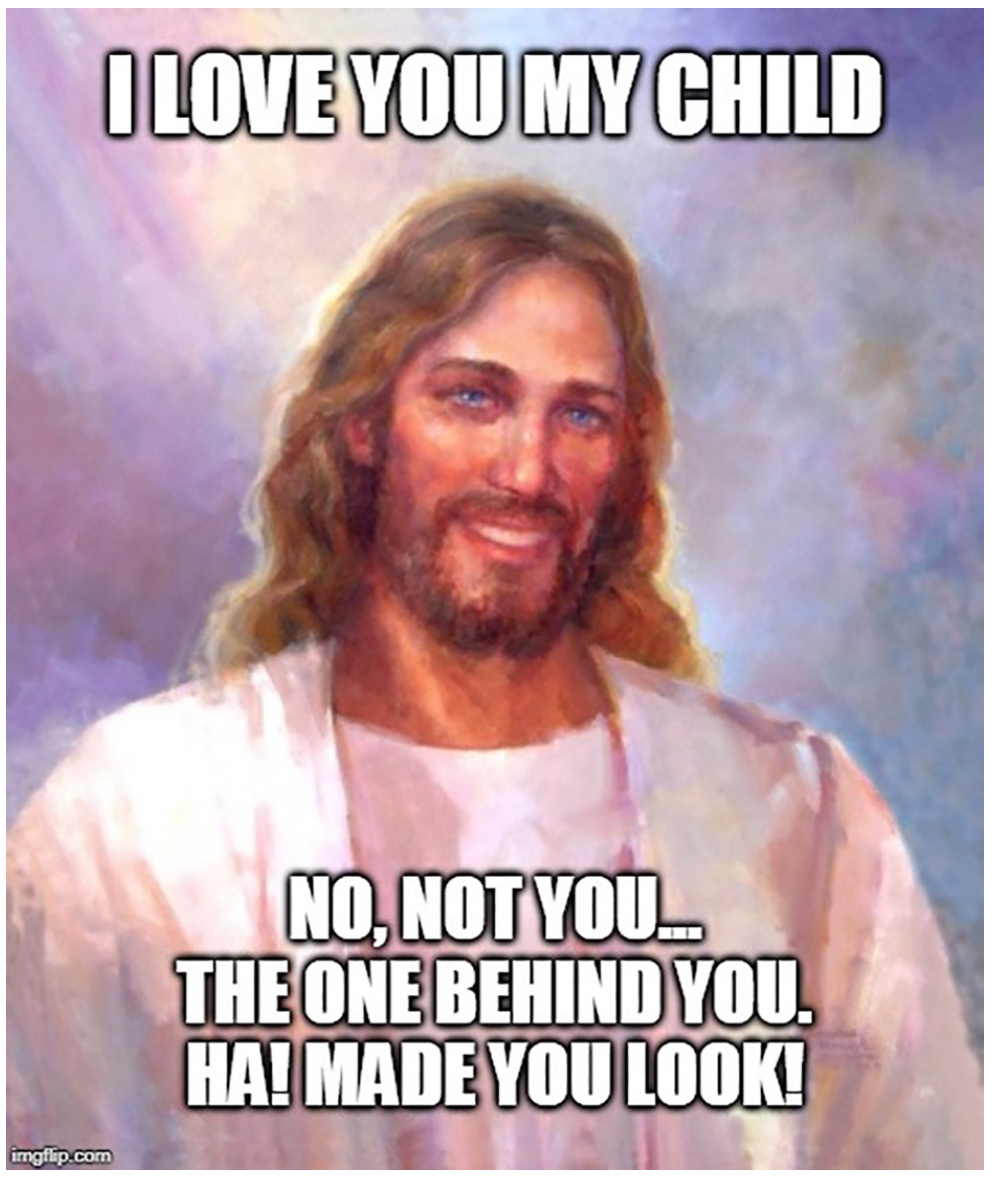

Figure 1. Example of a macro meme in set-up/punchline form [TikiHut, 2020].

Macros typically appear in a set-up/punchline form (see Figure 1) but there are deviations from this. Milner [2012] also identifies shops as memes that are created in image editing software to mix or combine multiple images into one meme. Macros and shops as well as hybrid versions of these are discussed below with respect to the COVID-19 crisis.

Crisis memes are created and disseminated during the cycle of a crisis. Crisis management suggests that crisis happens in stages that can be expressed simply as a "pre-crisis, crisis, and post-crisis" [Coombs, 2010, p. 22] paradigm. Crisis memes operate differently than other memes in that they add to the public discourse during a crisis in ways that might not happen via traditional means like press 
releases or news briefings and the understanding of their meaning is tethered to the crisis itself. Memes generated from crisis situations materialize for many reasons. They may be in response to the absurdity of the crisis, the seriousness of the crisis, the strange way a crisis response appears to citizens or for any other number of reasons. These memes would not exist without the crisis.

Merriam-Webster [2020] defines arena as "a sphere of interest, activity, or competition" or "a place or situation for controversy." Strauss [1978] takes this definition further by suggesting that arenas are social worlds where "various issues are debated, negotiated, fought out, forced and manipulated by representatives of implicated subworlds" (p. 124). The applicability of arenas to crisis communication was suggested by Frandsen and Johansen [2010] as a response to the static nature of previous theories of crisis communication where the paradigm places the organization at the center of the crisis as the dominant sender in a complex system. Rhetorical arena theory allows for scholars and practitioners to study complex communicative patterns of crisis situations from a multivocal perspective, giving voice to all the stakeholders affected by the crisis [Frandsen and Johansen, 2010]. A closely related and similar framework is issue arenas, first suggested by Luoma-aho and Vos [2010]. They contend that issue arenas are "places of interaction where an issue is discussed by stakeholders and organizations" [Luoma-aho and Vos, 2010, p. 317] and issue arenas offer a way to look at "the dynamic nature and multiplicity of [organizational] environments" [Luoma-aho and Vos, 2010, p. 318]. The COVID-19 crisis could very well be looked at from the issue arenas perspective and the results of the following analysis of crisis memes would still stand. Frandsen and Johansen [2010] lay out two models for analyzing crisis communication in the rhetorical arena, one at the macro and another at the micro level. The micro model is used to analyze the quality and character of individual communicative exchanges within the rhetorical arena [Frandsen and Johansen, 2010]. Since this paper is looking at crisis memes meaning-making and not at the relationships between the creator of the meme and the receiver of the meme, the micro level does not apply.

On the other hand, the macro level which "provides an analytical overview of actors or voices in the rhetorical arena" [Frandsen and Johansen, 2010, p. 433] is paramount to the analysis of crisis memes. When the public health crisis started, a COVID-19 rhetorical arena emerged populated by all the various actors (see Figure 2). Figure 3 is an example that illustrates how all the actors and stakeholders emerge in the COVID-19 rhetorical arena after a single press briefing.

These actors all speak to each other, about each other or against each other in the rhetorical arena where their "voices meet and compete, collaborate and negotiate" [Frandsen and Johansen, 2010, p. 433].

In a nationally televised briefing on April 23, 2020, President Trump suggested that medical researchers should look into the possibility of injecting disinfectant into the lungs to fight COVID-19. Journalists immediately began reporting on President Trump's disinfectant idea [D. Clark, 2020] and multiple actors of the COVID-19 rhetorical arena began to weigh in (see Figure 3). The makers of Lysol, a popular 


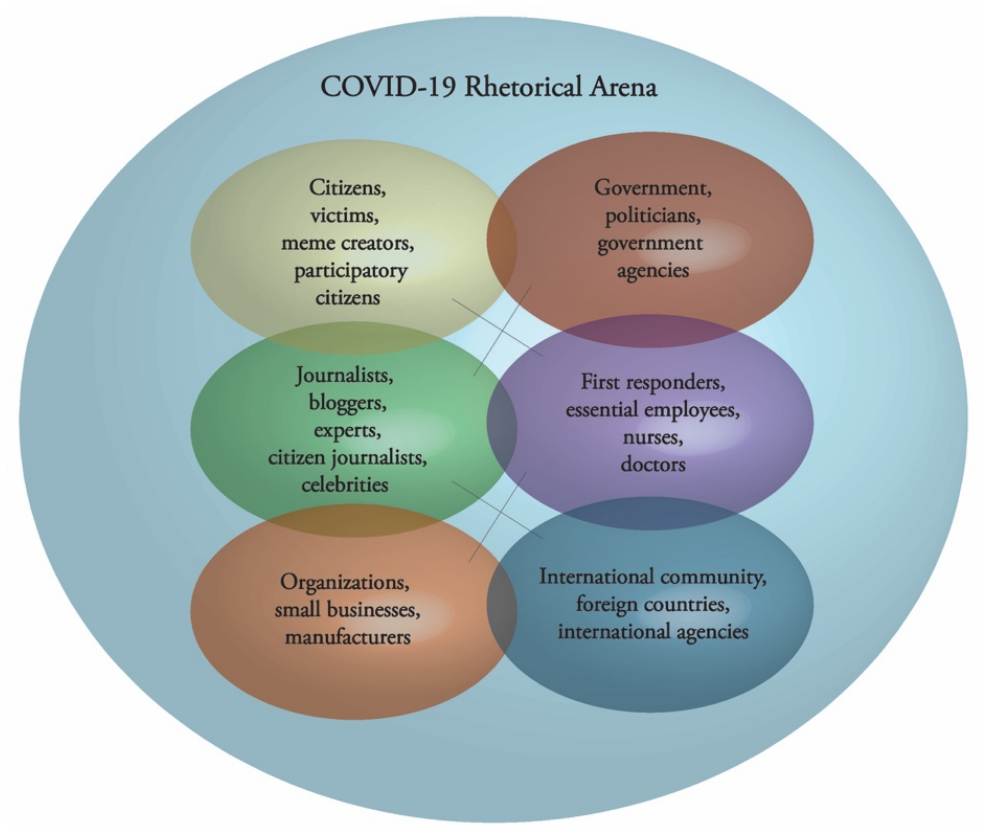

Figure 2. COVID-19 Rhetorical Arena with examples of actors.

brand of disinfectant, released a statement to the press and also updated their website saying that "under no circumstance should our disinfectant products be administered into the human body (through injection, ingestion, or any other route) [emphasis in original]" [Reckitt Benckiser, 2020]. The United States Environmental Protection Agency [2020], a government agency under President Trump's leadership, issued a press release reminding people to "not ingest disinfectant products" (para. 3). In what Grynbaum [2020] of the New York Times

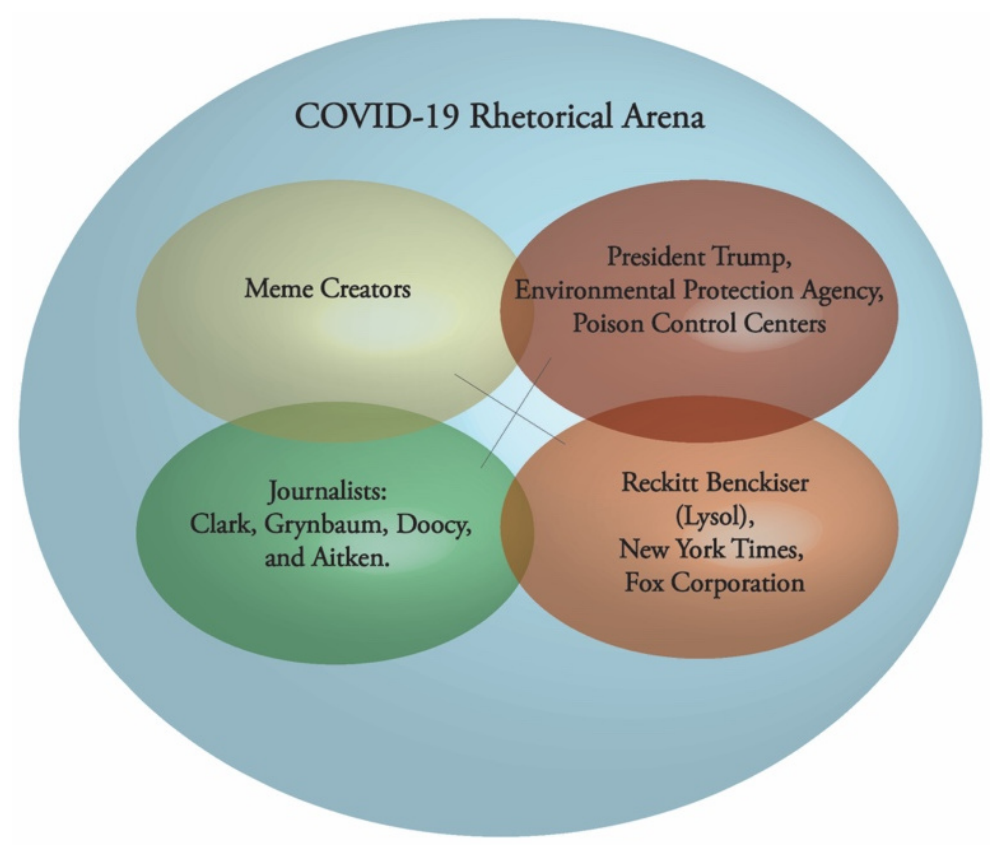

Figure 3. Emerging actors in the arena following a press briefing on April 23, 2020. 
characterized as a "rare fissure between the president and Fox \& Friends" (para. 4), Steve Doocy, the host, along with other Fox personalities that day issued warnings to their viewers. By 8:00 AM on April 24, 2020 the search term "injecting disinfectant" and related search terms were trending on Google (see Figure 4) demonstrating that most citizens were trying to determine if the reports were true or perhaps they were trying to find out more information on how to administer disinfectants into their bodies.

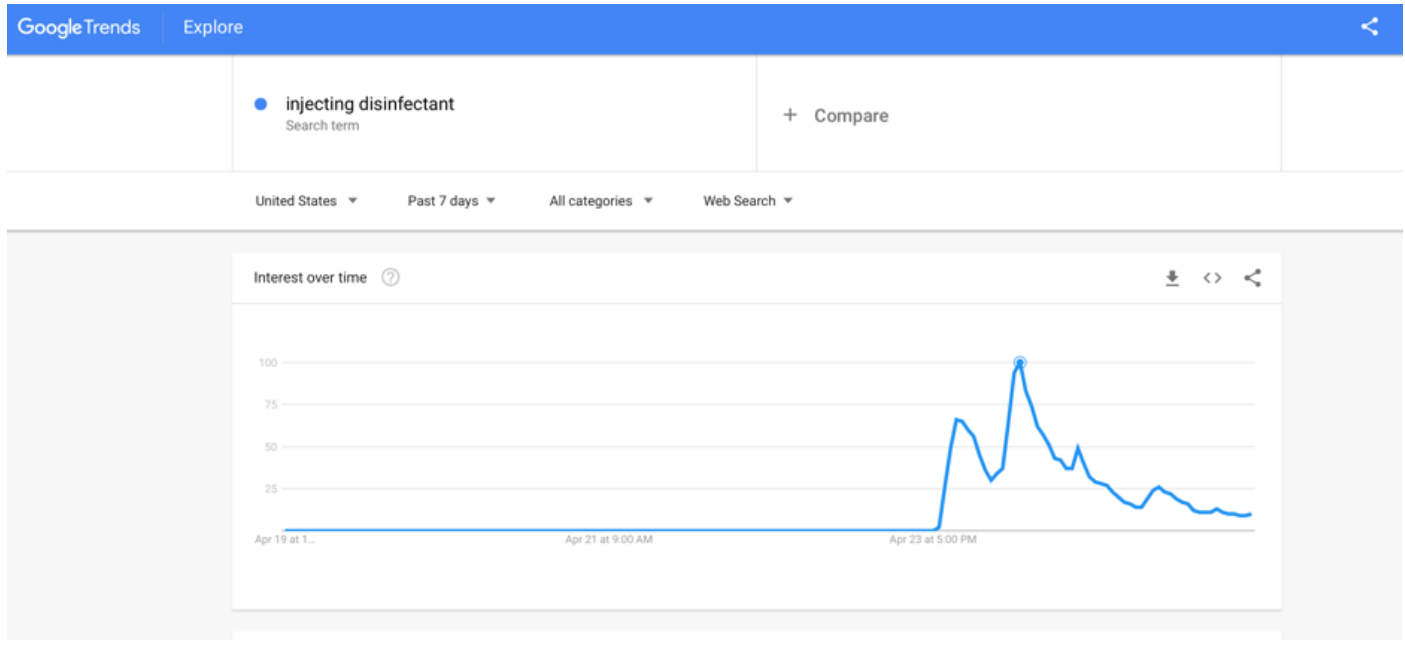

Figure 4. Google trends showing the peak of searches for injecting disinfectant on April 24, 2020.

By that point, many with social media accounts started participating in the public discourse on injecting disinfectants, some expressing their incredulousness and others attacking the media for creating fake news. It is important to note that later in the original April 23 news briefing President Trump clarified that "It wouldn't be through injection" [The White House, 2020]. On Friday, April 24 President Trump claimed that he was being sarcastic at the April 23 briefing, but unfortunately state poison control centers had already received a surge of calls asking questions and reporting exposure to disinfectants and bleach [Aitken, 2020]. This is not a full-scale content analysis of all the actors and voices around this particular communicative process within the COVID-19 rhetorical arena. In response to and making commentary about the disinfectant topic, meme creators designed and disseminated humorous memes that demonstrated their attitude towards President Trump's outrageous suggestion (see Figure 5 and Figure 6).

\section{Multimodality}

Multimodality, influenced by social semiotics, looks at meaning-making as a system of social interpretation [Jewitt, 2013, p. 250]. Van Leeuwen [2005] describes social semiotics as a "form of inquiry" (p. 1) that allows for the understanding of "the way people... produce communicative artefacts and events and to interpret them... in the context of specific social situations and practices" (xi.). Social semioticians see artefacts and events as resource rich and they are not limited to speech and text but are inclusive of images, sound, architecture, environments, and 


\section{Thank you Mr President}

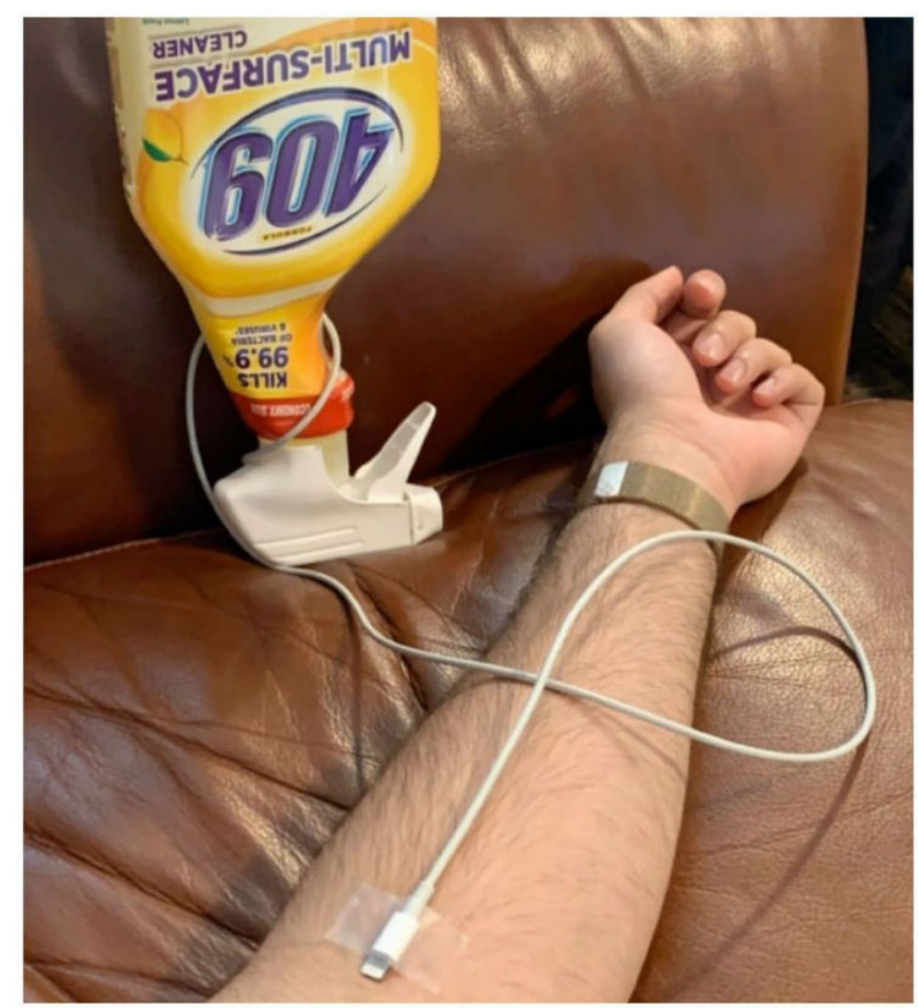

Figure 5. Injecting disinfectant Trump Lysol Clorox Meme [shutupandtakemymoney.com, 2020].

even actions like walking, among others [Van Leeuwen, 2005]. These semiotic resources are packed with the potential to make meaning "based on their past uses, and a set of affordances based on their possible uses, and these will be actualized in concrete social contexts where their use is subject to some form of semiotic regime" [Van Leeuwen, 2005, p. 285]. Semiotic resources are the expansive meaning-making ingredients behind modes, which are at the heart of the multimodal approach.

Modes are "socially and culturally shaped resources for meaning-making" [Jewitt, 2013, p. 253], and can be "language, images, gesture, typography, graphics, icons, or sound" [Siefkes, 2015, p. 114]. When many semiotic modes come together to make meaning, a multimodal ensemble emerges [Jewitt, 2013, p. 254]. These modes can work in concert (intermodally), one mode can dominate another, or one mode can work in opposition because the "The different aspects of meaning are carried in different ways by each of the modes in the ensemble" [Jewitt, 2013, p. 255]. Kress [n.d.] asserts that a mode is a "connected cultural resource for (representation as) meaning-making by members of a social group at a particular moment [emphasis in original]" (p. 38). Looking at crisis memes through the prism of multimodality provides an approach "to create an inventory of the meaning potentials..." [Jewitt, 2013, p. 256] of the modes associated with a particular meme.

As an example of a multimodal analysis including an inventory of semiotic resources, take a close look at Time's December 22, 1980 cover (see Figure 7). The following modes are evident: 


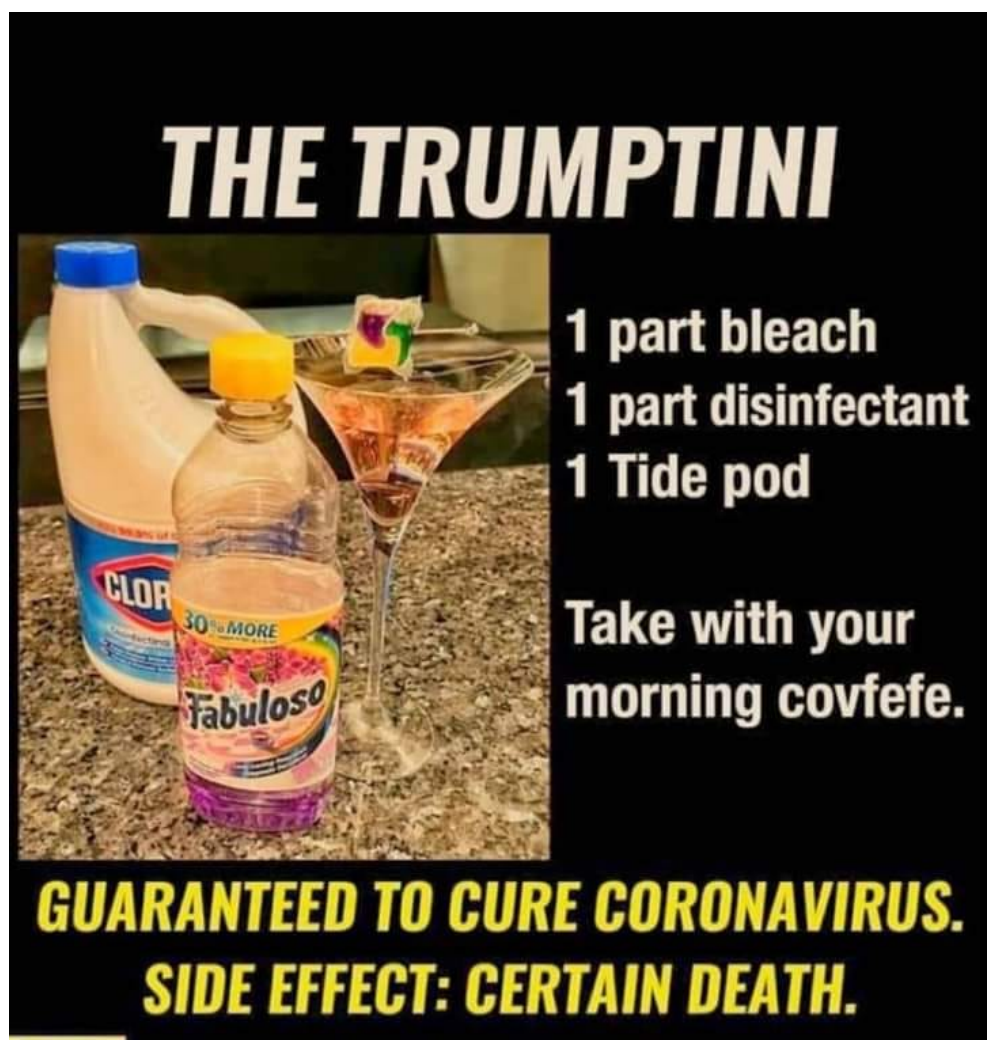

Figure 6. The Trumptini Clorox drink meme [somethingtolaughat.com, 2020].

1. The magazine itself inclusive of a bar code and its iconic red border

2. The text of varying sizes and colors

3. An image/painting of John Lennon (dominant mode)

4. An icon/vector graphic of a tank offset outside the red border in a two-tone box

Even though the overall image of Time's cover is two-dimensional on the page in this paper, it refers to a three-dimensional artifact, a magazine. Attached to a magazine as a mode are all the semiotic resources associated with it including the history of magazines themselves. For example, magazines are different from newspapers in that they are typically published less frequently, usually have considerably more in-depth coverage of their topics, and are created on finer quality paper with high resolution images. In addition, and with more specificity, Time magazine has its own storied history and reputation that includes such things as their much talked about person of the year cover and their iconic red border implying that anything within it involved "careful thinking, writing, reporting and arresting images" [Stengel, 2010, para. 1]. The text for the title "Time" is in its recognizable font, prominently featured at its typical placement on the page and in the magazine's signature red color.

At the time when this magazine hit the newsstands, anyone who ran across it already knew the date and the significance of the image of John Lennon, making his image the dominant mode. Looking at it historically, the date on the cover lets us know that this magazine was published two weeks after the murder of John 


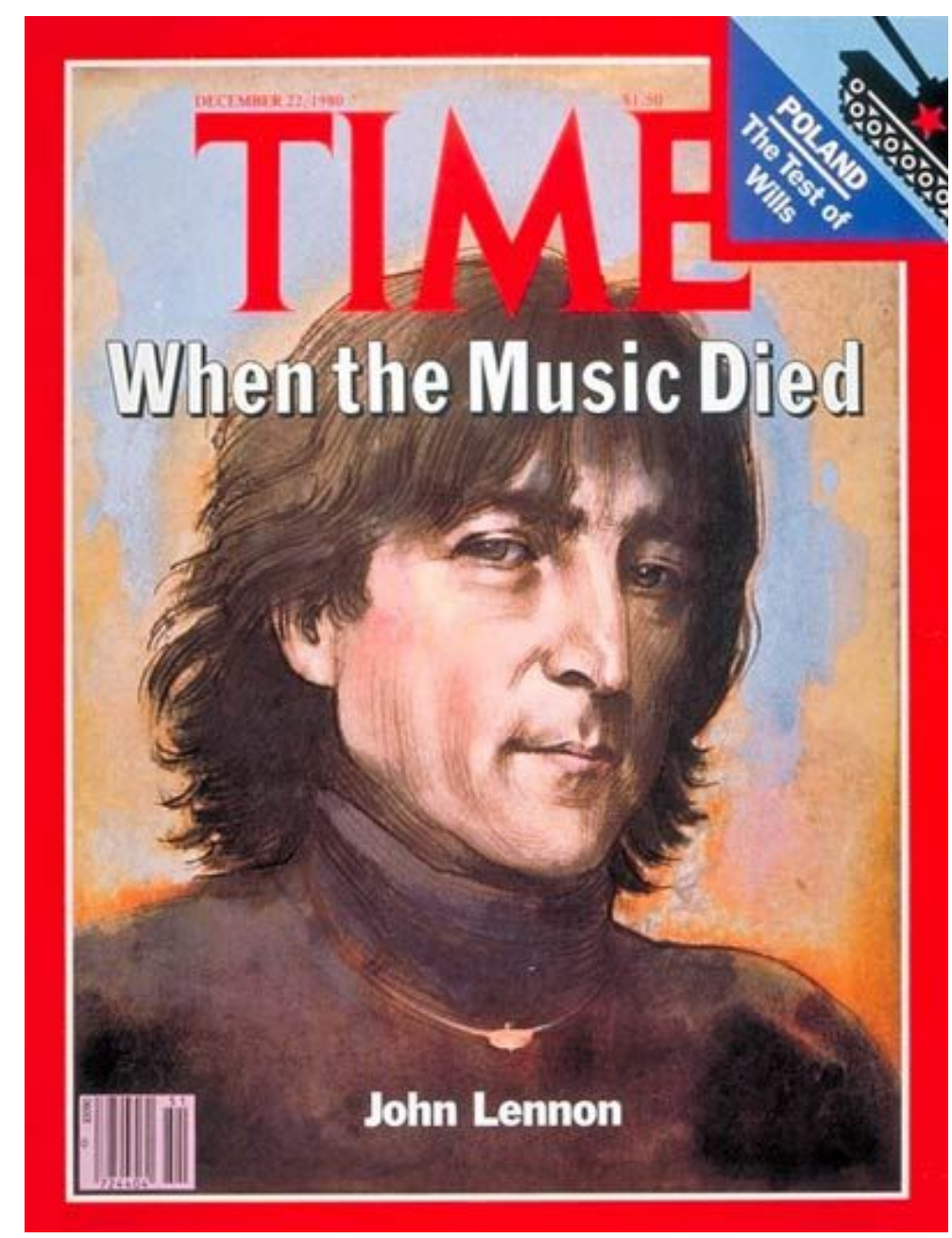

Figure 7. When the Music Died. From TIME. (c) 1980. TIME USA LLC. All rights reserved. Used under license. https://time.com/.

Lennon. The text "When the Music Died" is particularly loaded with meanings with its significance indicated, in part, by the font choice, placement and size. One potentiality the text draws up is the Don McLean song "American Pie" with its iconic first verse leading into the chorus where Mclean sings "But something touched me deep inside, the day the music died" [Genius, 2020]. McLean says that the first verse of the song is specifically about the day Buddy Holly, Richie Valens, J.P. "The Big Bopper" Richardson, and their pilot died in a fiery plane crash [Martoccio, 2019]. "When the music died" could also simply refer back to the day the Beatles broke up or the sad truth that without Lennon, there is no chance for The Fab Four to reunite.

Time chose an illustration of Lennon rather than a photo. The background of the photo contains sky blue tones with reds and oranges illuminating and reflecting off of what appear to be clouds. This background image emotes a sunset, perhaps in reference to the sun setting on a rock and roll icon's life and legacy. Lennon's gaze is fixed on the viewer and hints at peace and serenity. His hair evokes movement since it is not lying flat against his neck but appears to be flaring out. The turtleneck intimates cold or taken together with all the reds and browns of the entire illustration implies a change of season, from fall to winter, from life to death. 
In the upper right-hand corner is an icon of a tank and more text offset from the cover indicating the unrelated nature of that story from the cover story but also giving it prominence on the cover of the magazine. Taken together, Poland and the tank imply some kind of military operation. This is not an exhaustive inventory of all the meanings potentially produced by this cultural artifact, but it serves to illustrate a multimodal analysis. The overarching research question of this article is:

RQ: How do crisis memes produce meaning that demonstrate the attitudes and experiences expressed by actors during a crisis?

\section{Methodology}

\section{COVID-19 crisis} memes
Purposeful sampling was utilized to select the individual memes used for analysis. Patton [2014] says that purposeful sampling "permit[s] inquiry into and understanding of a phenomenon in depth [emphasis in the original]" (p. 52). The criterion employed to make each selection was that the meme needed to adhere to the definitions set out in the meme section above and they also had to be created during the ongoing crisis. Therefore, each meme needed to be a macro, shop or a hybrid of these two. Other meme types were excluded. Memes with themes similar to those of the crisis but created prior to the crisis were excluded. For example, anti-vaxxer memes were popular before the crisis and could very well be misunderstood as a COVID-19 crisis meme when they are not. The search terms were inspired by a glossary provided by the Yale School of Medicine [Katella, 2020]. Google Images was used to search and find the crisis memes. The following crisis memes were chosen to maximize in-depth analysis of modes and semiotic resources and to create a clear picture of the experience of living through the pandemic. Special attention in the selection process was given to memes that demonstrated how actors and stakeholders talked to and about each other within the rhetorical arena.

\section{Social distancing crisis memes}

As parts of the world went into quarantine, many people decided to watch some films about public health crises. One of the films that people put back in the top ten of the home video movie charts was the 2011 Stephen Soderbergh film Contagion [T. Clark, 2020]. Contagion follows the people that are affected as a virus spreads across the planet. These people are essentially all the actors expected to have a voice in a rhetorical arena: a father trying to protect his daughter as the pandemic sets in, a Center for Disease Control doctor sent into America's ground zero to track the disease, a citizen journalist reporting conspiracy theories, doctors and policy makers from the World Health Organization, local government, and so on. The fiction film got a lot of things right including social distancing. Bringing the Beatles back into the conversation, look at Figure 8 . This image is a shop, digitally altered in a photo editing program to create a meme. Even though there is no text, this altered image qualifies as a crisis meme with two modes. The shopped photo is one mode and the crisis itself is the other more dominated mode. Even though the crisis is unseen it dominates the production of meaning because the meme would not make sense without the context of the COVID-19 pandemic. The photo is an altered version of the iconic album cover of the Beatles' Abbey Road, their penultimate recording, which was their first "front cover [that] contained neither 
the group's name nor the album title" [Apple Corps, 2020]. Stanley [2020] released the meme through his twitter account on March 20 with the tag line "Well done, lads." Of course, it works without the tag line because it has been created and shared during the cycle of the crisis. One of Stanley's [2020] followers responds with a remixed version of this meme (see Figure 9) with each member of the band wearing a face mask. This communicative exchange between Stanley and his follower demonstrates how this particular crisis meme is used by actors in the rhetorical arena to make statements about the crisis to each other and to other actors, one highlighting the importance of social distancing and the other on utilizing face masks as an extra layer of protection. These two actors, or meme creators, show their understanding and support of health and science experts who came out to say that social distancing and mask wearing could save lives (even when some government officials were still hesitant on suggesting or requiring such precautions).

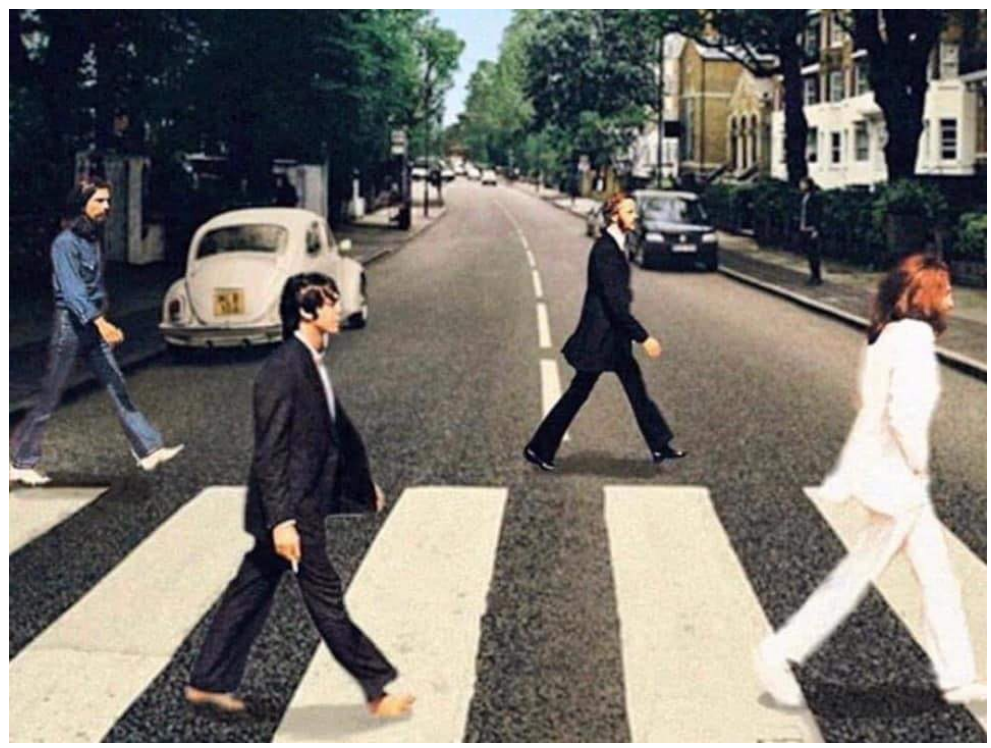

Figure 8. Good job, lads [Stanley, 2020].

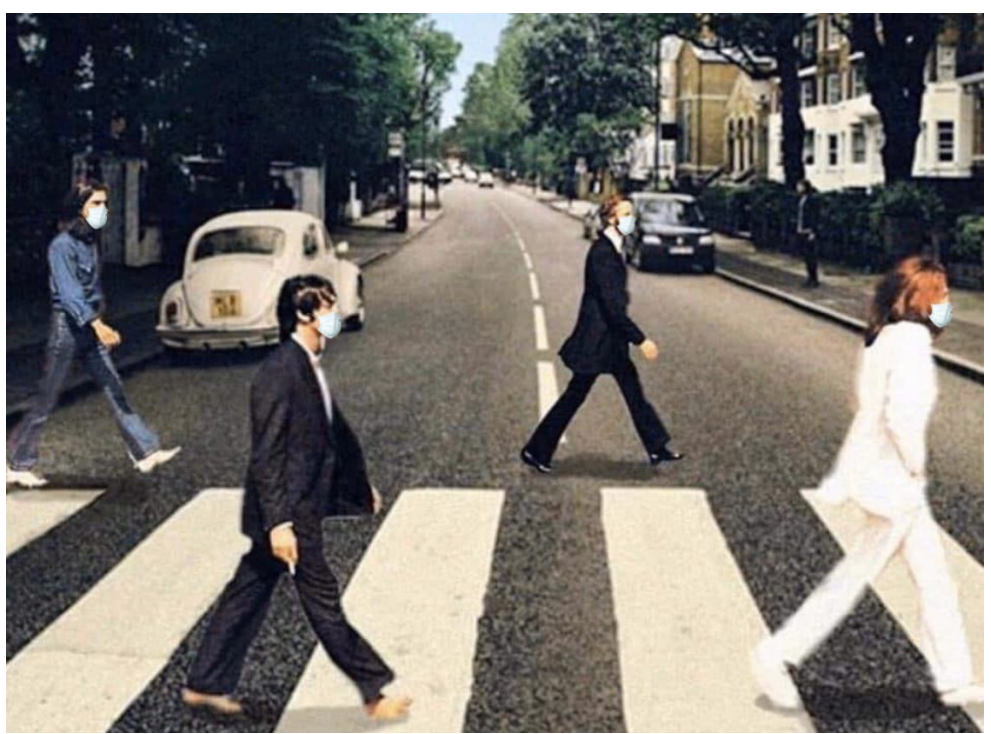

Figure 9. They had a fine eye for detail [Art by EQ, 2020]. 
The affordances that crisis memes, their modes, and semiotic resources offer are wide and varied. The Star Trek social distance meme (Figure 10) is jam packed with potential meaning.

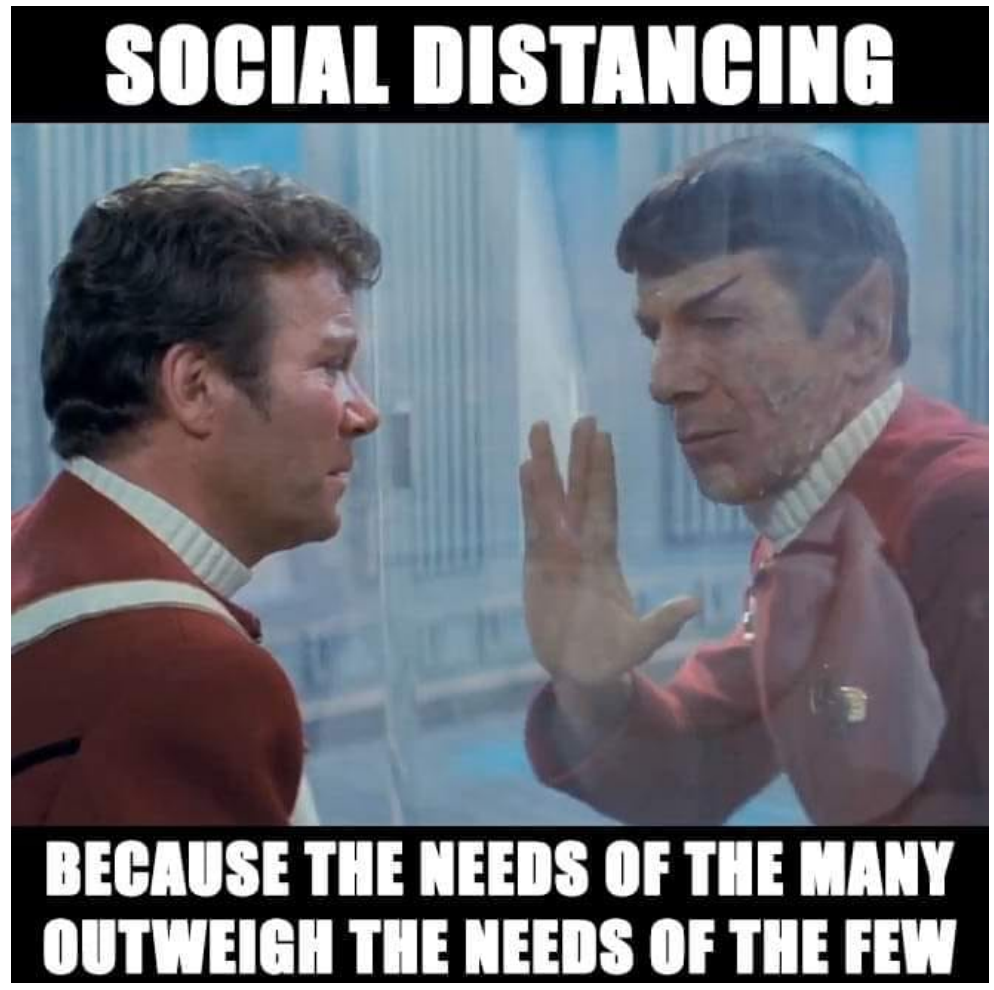

Figure 10. Star Trek Social Distancing Meme [Star Trek Discovery Memes, 2020].

The following is a list of modes for this particular crisis meme:

1. The COVID-19 pandemic crisis (dominant mode)

2. The image mode from Star Trek

3. The text

The meme creator uses an image taken from an iconic scene in Star Trek II: The Wrath of Khan where Spock, played by the late Leonard Nimoy, dies of radiation poisoning after sacrificing himself to fix the main engine of the spaceship. The Vulcan salute is a hand gesture that is often related to the mantra "live long and prosper" [Foran, Fox and Herb, 2020, para. 4] and was suggested to U.S. lawmakers by a physician as "a safe alternative to handshaking" [Cooper, 2020, para. 1]. In Cooper's [2020] article a menagerie of actors and stakeholders emerge that participate in the rhetorical arena. Minnesota Rep. Dean Phillips (government official) told CNN about the health expert's suggestion and then Cooper (journalist) went on to say that she had made the recommendation a week before. How or when or if this inspired the meme creator is difficult to determine but it is clear that the discourse regarding the Vulcan salute was at play in the COVID-19 arena.

Looking closer at the ways the modes work together to produce meaning, the interplay between the text mode and image mode tells everyday citizens that we all 
can be heroes like Spock who died to protect the entire crew of the Enterprise. The meme creator is sending a message to others in the rhetorical arena about helping each other out by following the advice of health and science experts to practice social distancing. There is still much more here that keys into the production of meaning. Leonard Nimoy died of chronic obstructive pulmonary disease (COPD), a respiratory disease, and one of COVID-19's symptoms is trouble breathing. Kirk and Spock are separated by a wall of glass in the image mode and this brings to mind all the stories in the news of people not being able to see their loved ones as they pass and how some people watched family members die through a hospital room window or via video chat.

It seems as though the crisis meme creators often send messages to other actors in the rhetorical arena regarding their behavior during the crisis, even if it is sometimes couched in humor. Figure 11's image mode shows a new reality of waiting in line to go into the grocery store with one caveat: there appears to be a cat also waiting to get in. The text mode suggests that even a simple house cat is smarter than some people who appear to be incapable of following social distancing guidelines. Figure 12's image mode shows Mrs. Kravitz, the quirky, nosey neighbor of Samantha Stevens, the beloved witch of the classic television series Bewitched, peering through her window monitoring her neighbor's social distancing. Local government officials created special methods for reporting instances of social distancing violations and people do not even have to pick up the phone, they can just text a photo [Ruiz, 2020]. This has set up a tension between those who think reporting violations is ratting someone out and those who think it is their duty as participatory citizens. The use of the word Nazi in the text mode is unfortunate but also points to a terrible past where "denunciation was commonplace under the Communists in East Germany and Hitler's Nazis" [Chambers, 2020, para. 2]. The meme creators have voice via their memes and also give voice to actors within the rhetorical arena. As participatory citizens, the meme creators express the views of everyday folks like those who flout social distancing rules or those who feel it is unnecessary to police other citizens. The complexity of these voices within the rhetorical arena can be understood by simply looking at the multimodal nature of crisis memes.

\section{N95 respirator crisis memes}

The tension between government officials, health experts, scientists and citizens regarding the use (and proper use) of masks as a potential weapon against

COVID-19 started early in the crisis and continues to this very day. To wear or not to wear, to require or not require is a narrative that has raged within the rhetorical arena, often times adding to the confusion as citizens look for advice on what to do. President Xi Jinping of China was the first leader to wear a mask in public [Noack, 2020]. He wore a surgical mask in what some deemed a signal to not panic and to avoid N95 respirators which are used by medical professionals [Business Today, 2020]. President Trump avoided being pictured wearing a mask suggesting that he was not using them at all until as late as July 20, 2020 when he declared via Twitter that wearing masks was patriotic [Breuninger, 2020]. With the rise of misinformation and anti-maskers, scientists and health experts continued to add to the public discourse about the benefits of face coverings. In fact, as late as August 2020 scientists were still conducting experiments to demonstrate to the public the 
Not sure what the cat needs but it knows how to follow rules

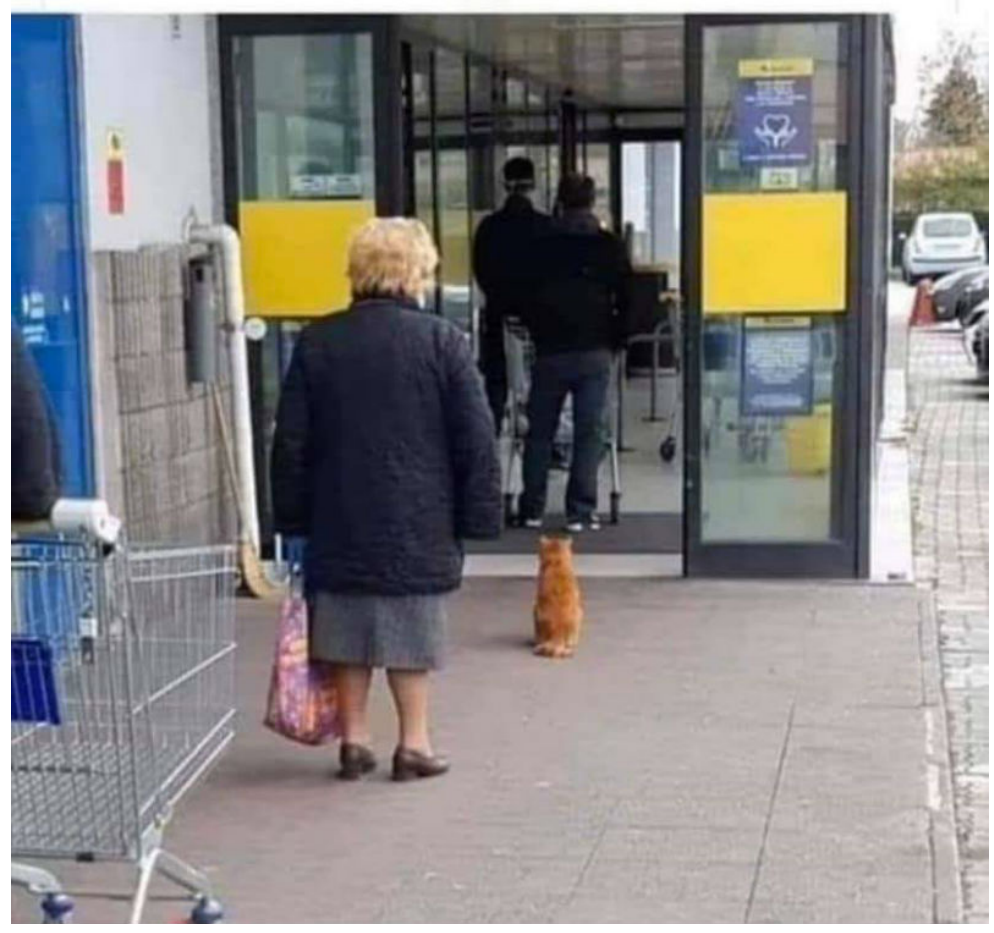

Figure 11. A polite cat meme [cheezburger.com, 2020].

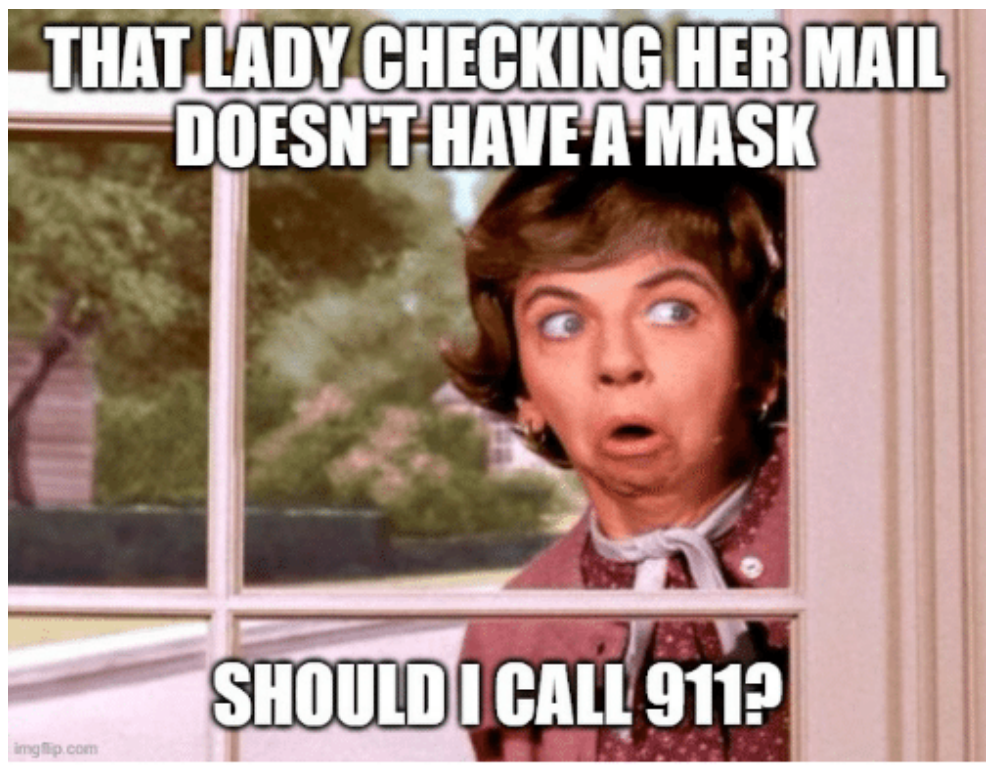

\section{Social Distancing Nazi}

Figure 12. Social Distancing Nazi meme [me.me, 2020].

effectiveness of face coverings as well as which ones worked the best [Dockrill, 2020]. As these actors and stakeholders participated in the public discourse around facemasks, meme creators weighed in. 
During the pre-crisis stage of the pandemic nervous citizens started panic buying face masks which lead the surgeon general to issue a plea via Twitter asking people to stop and he also suggested that there were limits to the effectiveness of masks [Cramer and Sheikh, 2020]. With all these mixed messages from officials and with a potential mask shortage looming, meme creators added humor to the discourse. Figure 13 is a macro meme made up of three modes:

1. The COVID-19 pandemic crisis (dominant mode)

2. The image of a man wearing an orange peel

3. The text as a punchline
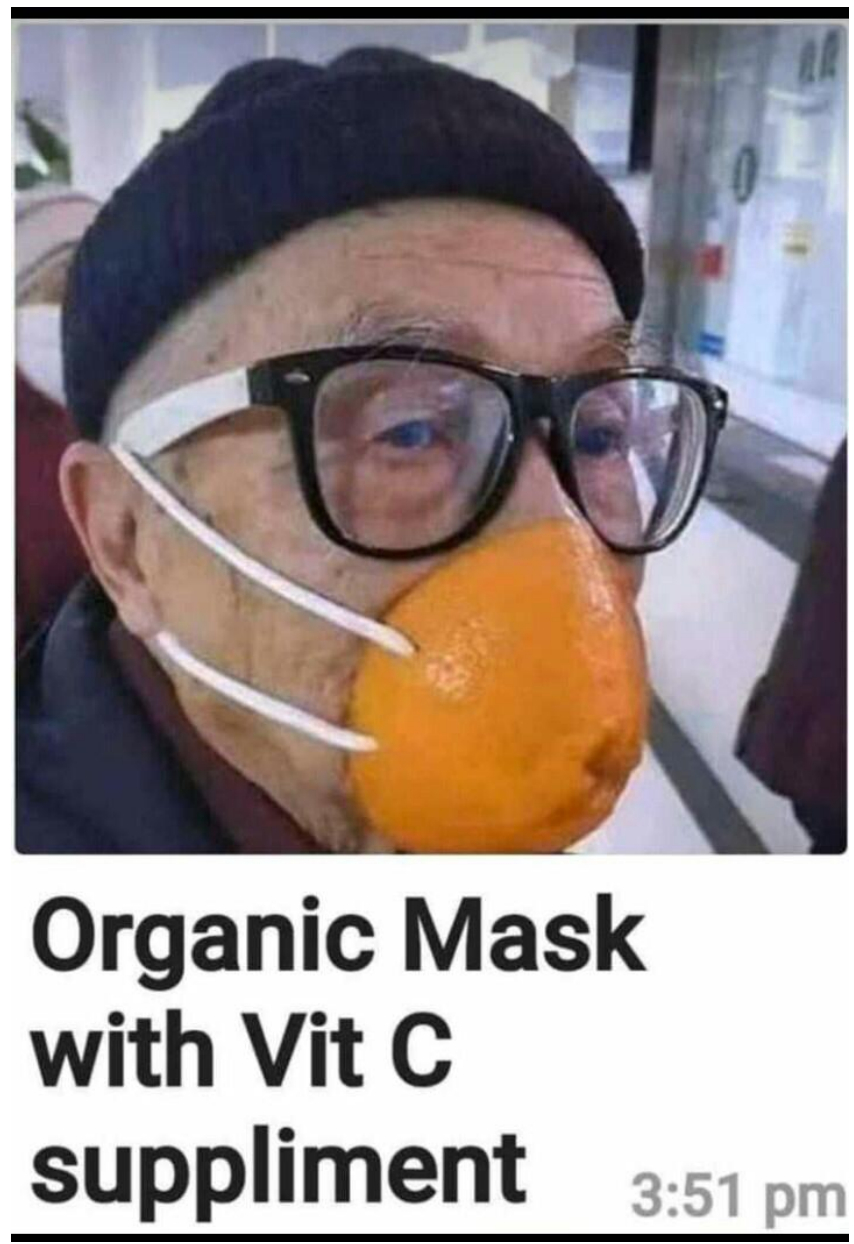

Figure 13. Innovative Masks [Rosy [@rose_ko1], 2020].

It is difficult to determine but easy to imagine that this particular meme was staged rather than a found image. The meme creator creates a message that perpetuates the idea that if you cannot buy a mask, you can do-it-yourself (DIY). Many memes circulated that showed citizens' DIY masks including ones that showed a man wearing bread, a woman with her underwear on her face, and, jokingly, a man with an old anti-virus compact disk over his mouth and nose. The punchline and the crisis mode work together to create meaning that is an indictment of the lack of preparedness of the government and supply chains when the pandemic hit. If wearing a mask is suggested (or required) but there are no masks to be found, what 
can a person do? Vitamin $C$ is a vital nutrient that health professionals recommend citizens have an average daily allowance [National Institutes of Health, 2020] but with all the misinformation about COVID-19, the vagueness of what will actually be effective in stopping the spread creates confusion. Is vitamin $C$ another layer of protection? Long after citizens posted to their social media on how to create your own masks from materials at home, the Centers for Disease Control and Prevention (CDC) finally released a webpage dedicated to DIY mask making [Centers for Disease Control and Prevention, 2020a].

Many people had never worn a mask before. Vigilant health professionals took to social media platforms to demonstrate via video how to properly put on a face covering, sometimes aimed at everyday citizens and sometimes aimed at other health professionals [Renown Health, 2020; MassGeneralHospital, 2020]. Meme creators added to the discourse about the proper way to wear a mask with comical memes. Consider Figure 14 in which a woman takes the notion of wearing a face covering a bit too far.

\section{Product package said "FACE" mask}

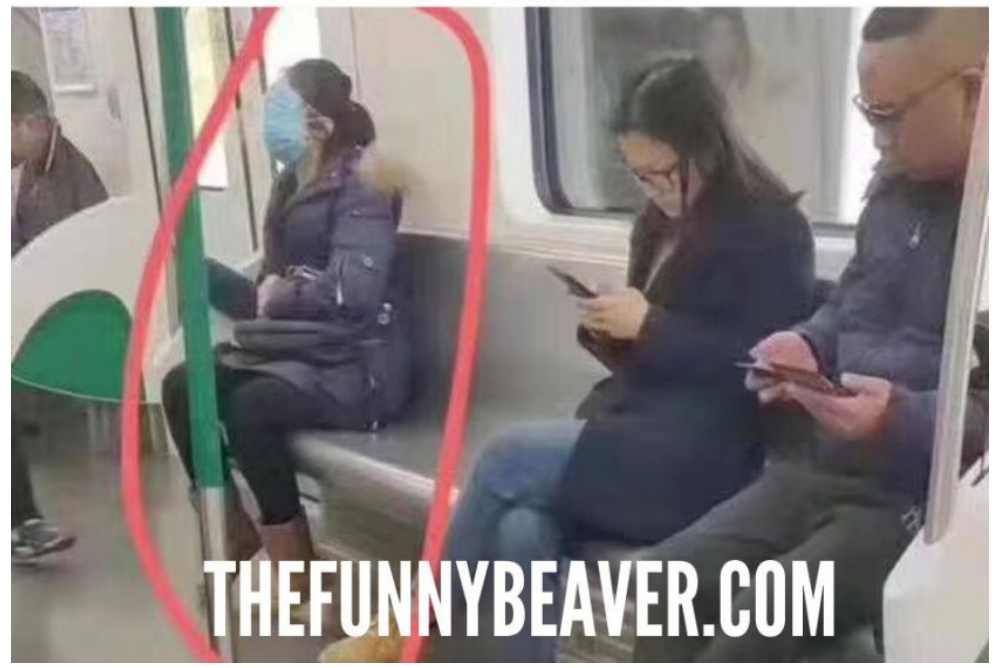

Figure 14. This woman doesn't mess around [The Funny Beaver, 2020].

The text mode suggests that the woman took the word face literally. The hard truth is that most people were not privy to how to put on a mask or how to take it off and although health experts took it upon themselves to educate the public, the government failed to take the lead in this particular situation.

As the crisis dragged on, anti-maskers emerged as actors in the rhetorical arena. They claim that local and federal governments overreach when requiring face masks and that such mandates are an infringement of their constitutional rights [Stewart, 2020]. Meme creators responded with incredulity and humor. Figure 15 is an attack on the absurdity of anti-maskers and how they get their (mis)information, which is clearly not from health or science experts. The meme cautions people to listen to health and science experts. 


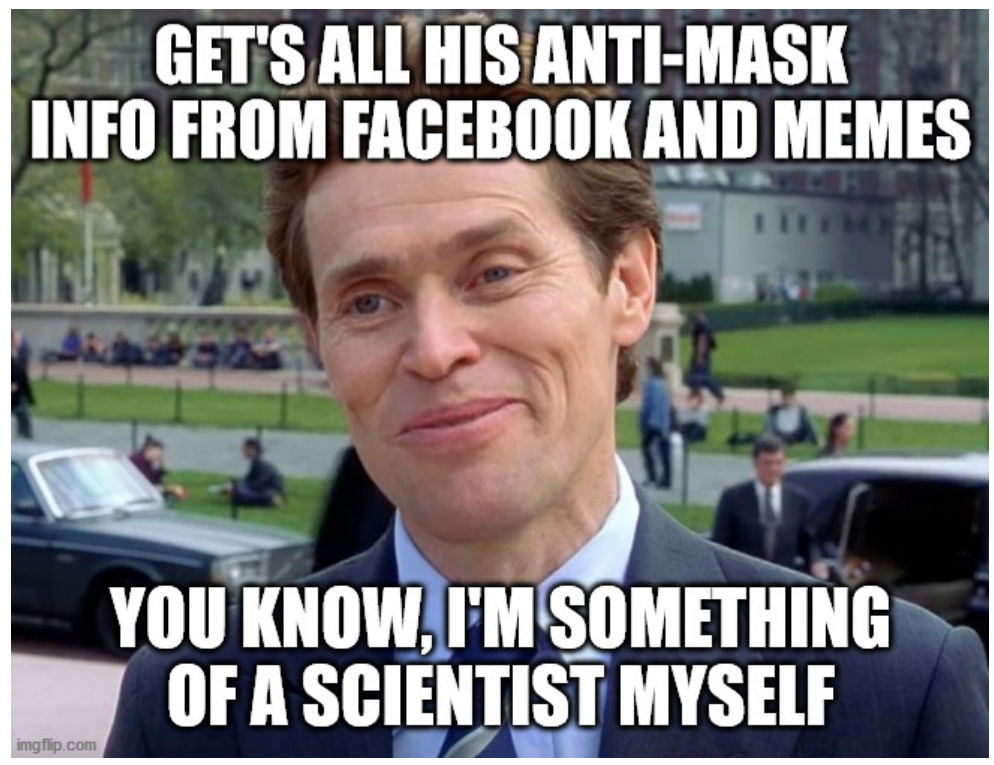

Figure 15. Anti-Maskers [Reddit, 2020].

The meme includes the following modes:

1. The COVID-19 pandemic crisis (dominant mode)

2. An image of Willem Defoe as a comic book villain

3. The text with a set-up/punchline structure

Willem Defoe appeared as Norman Osborn/Green Goblin in director Sam Raimi's 2002 live-action Spider-Man. Norman Osborn is a scientist turned villain in the Marvel Comics Universe. He conducts experiments on himself that drive him mad and turns him into the murderous Green Goblin. The punchline of the meme refers back to the character in such a way that expresses the meme creators' thoughts that anti-maskers are crazy, misinformed, and dangerous. Mask wearing became a partisan issue with liberals wearing masks more often than conservatives [Igielnik, 2020]. The increased visibility and voice of anti-maskers during the crisis forced the $\mathrm{CDC}$ to issue guidelines to frontline works (specifically retail and service businesses) to limit workplace violence as a result of people refusing to wear masks, social distance and follow other prevention policies at their places of business [Centers for Disease Control and Prevention, 2020b]. Since anti-maskers will not stay home even when ordered, the tension and controversy will continue.

\section{Stay at home crisis memes}

Stay at home orders inspired a wealth of crisis memes. Celebrities as actors in the rhetorical arena weighed in with messages of "we're all in this together" (see Figure 16). Pop superstar Madonna posted an image of herself in a milk bath along with fresh rose petals to her social media accounts declaring COVID-19 a great equalizer and inspiring some to say she was out of touch [Owoseje, 2020]. Of course, COVID-19 has disproportionately affected working class families and people of color [see Theoharis, 2020]. A crisis meme like Figure 16 expresses 
incredulousness and frustration with the inequities of the world and adds to the public discourse around privilege during the time of a pandemic.

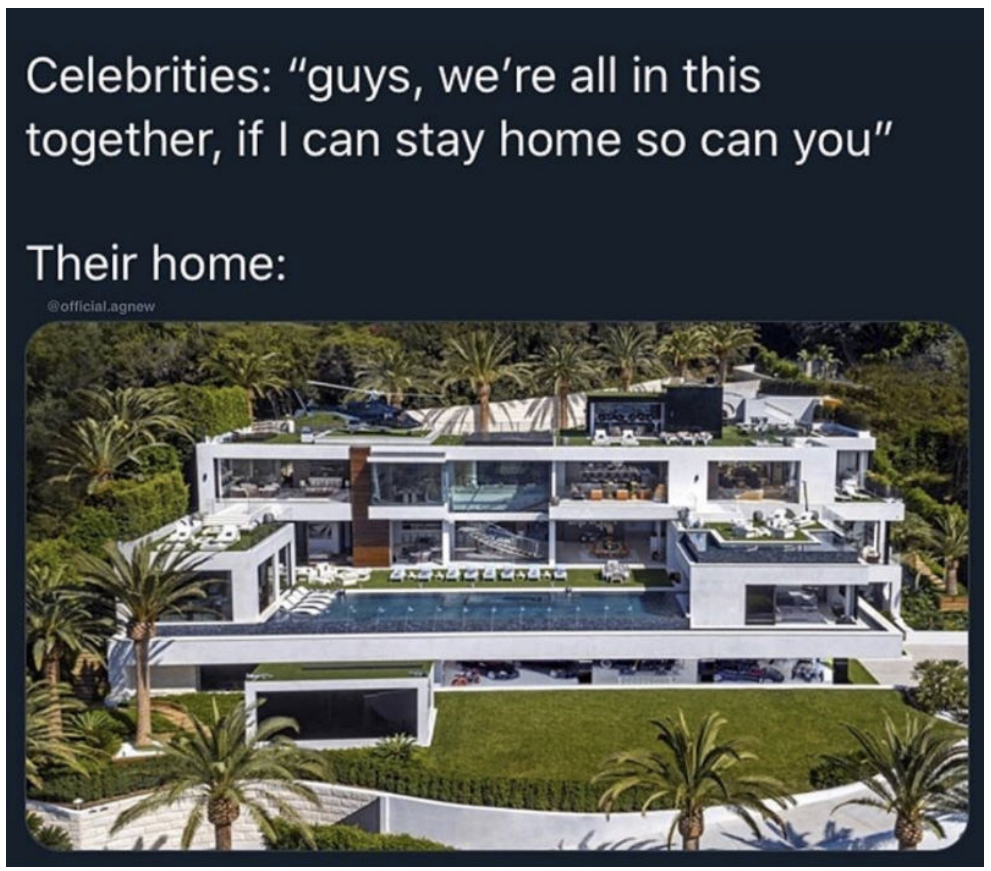

Figure 16. Celebrities: we're all in this together meme [Aaaadam [@official.agnew], 2020].

The messages could not be any clearer in Figures 17, 18 and 19. As people, particularly the young, became vocal about their dissatisfaction and frustration with stay at home orders, other participatory citizens designed crisis memes like Figure 17 suggesting staying home is not a national draft to war, it is not like life in a concentration camp, and the sacrifice is considerably small compared to the troubles of our nation's past. Anticipating a shortage of health care professionals, many states asked retired doctors and nurses to come out of retirement and help on the frontlines [De Avila and Chen, 2020]. Catching onto this, meme creators designed crisis memes that warned those ignoring stay at home orders of the potential consequences (see Figure 18 and 19).

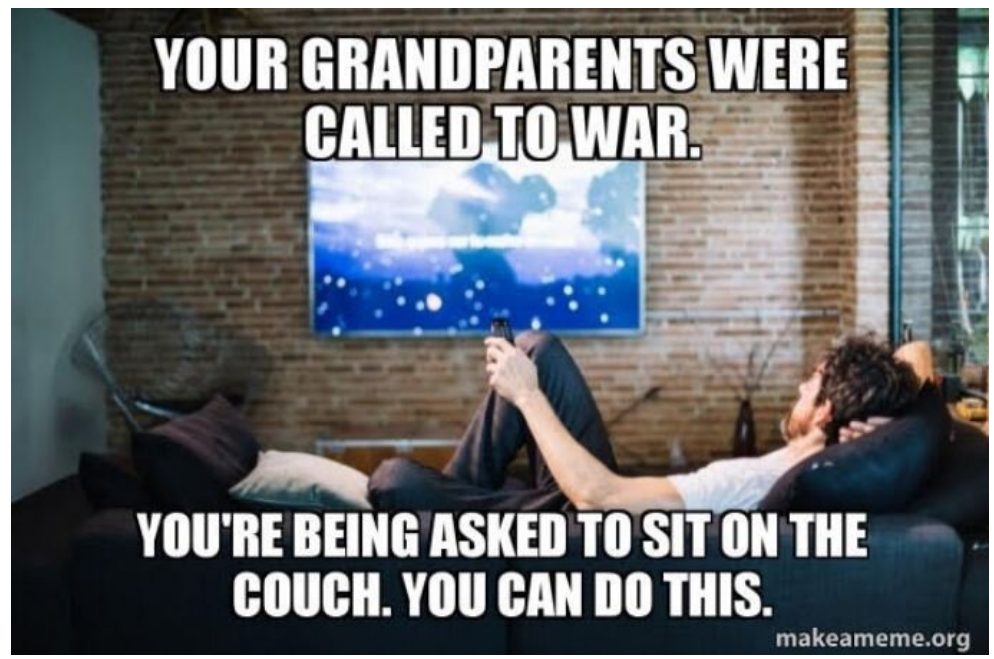

Figure 17. Your grandparents were called to war meme [makeameme.org, 2020]. 


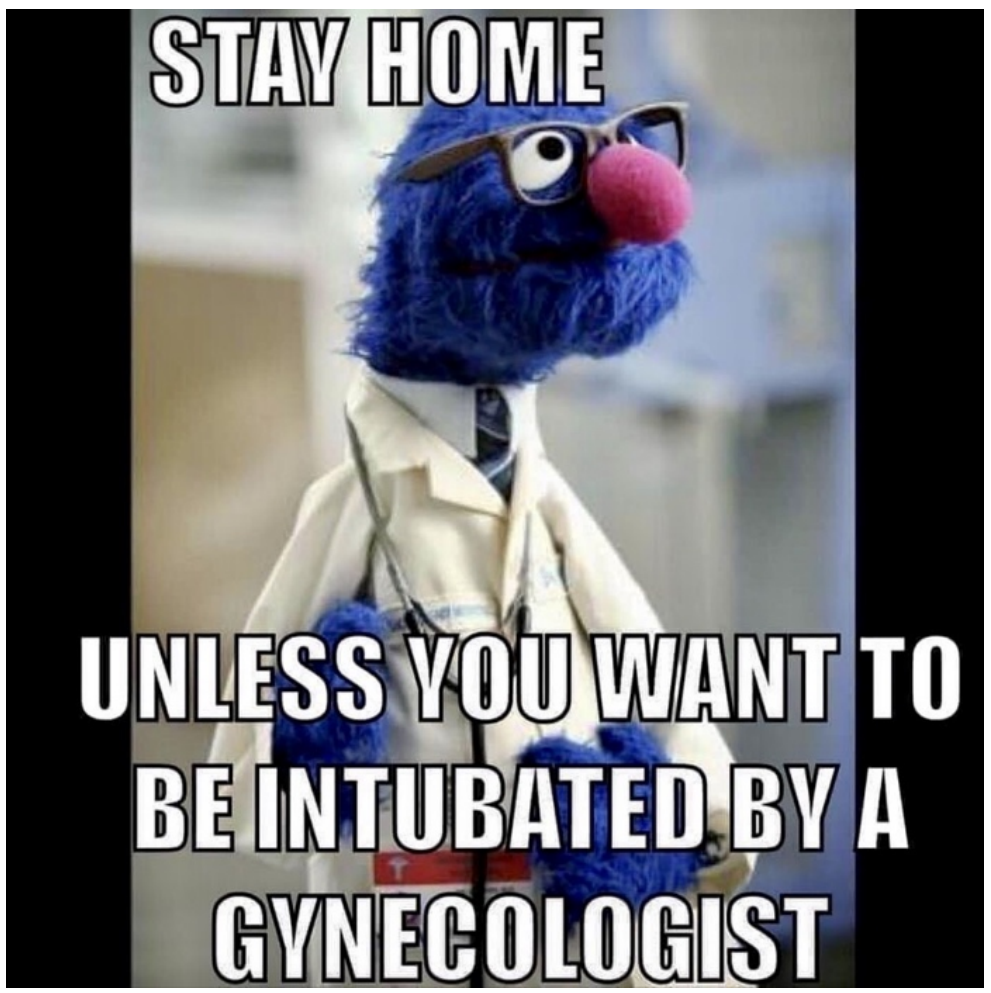

Figure 18. Stay home unless you want to be intubated by a gynecologist [Lapachinsky, 2020].

\section{COVID-19 vaccine crisis memes}

The COVID-19 crisis sent scientists into high gear to try to develop a vaccine. Scientist immediately felt pressure from multiple actors of the rhetorical arena including President Trump himself. At an early meeting with top researchers, Dr. Anthony Fauci, the director of the U.S. National Institute of Allergy and Infectious Disease, and others tried to explain the potential timeline to a deployable vaccine, insisting it would take more than a year [Rupar, 2020]. Rupar [2020] suggested that Trump's aim was to have a vaccine before the November election which exposed his ignorance about the scientific research process as well as the requirements set forth by the Food and Drug Administration (FDA), an agency under his leadership. As anti-vaxxers emerged in the rhetorical arena and conservative citizens rose up with misinformation to claim that COVID-19 was a democratic hoax, scientists and meme creators had their work cut out for them.

Take as an example Figure 20 which shows Bill Gates as the image mode with a set-up/punchline text. A 2015 speech of Gates' garnered new attention because in it he said that an infectious virus was "the greatest risk to humanity" [Wakabayashi, Alba and Tracy, 2020, para. 1]. This led conspiracy theorists and right-wing pundits to claim that the speech was proof "that one of the world's richest men planned to use a pandemic to wrest control of the global health system" [Wakabayashi, Alba and Tracy, 2020, para. 2].

The meme creator of this particular crisis meme sends a satirical message out to others in the rhetorical arena and adds to the discourse around the Bill Gates narrative. This particular image of Bill Gates has been remixed and reused with 

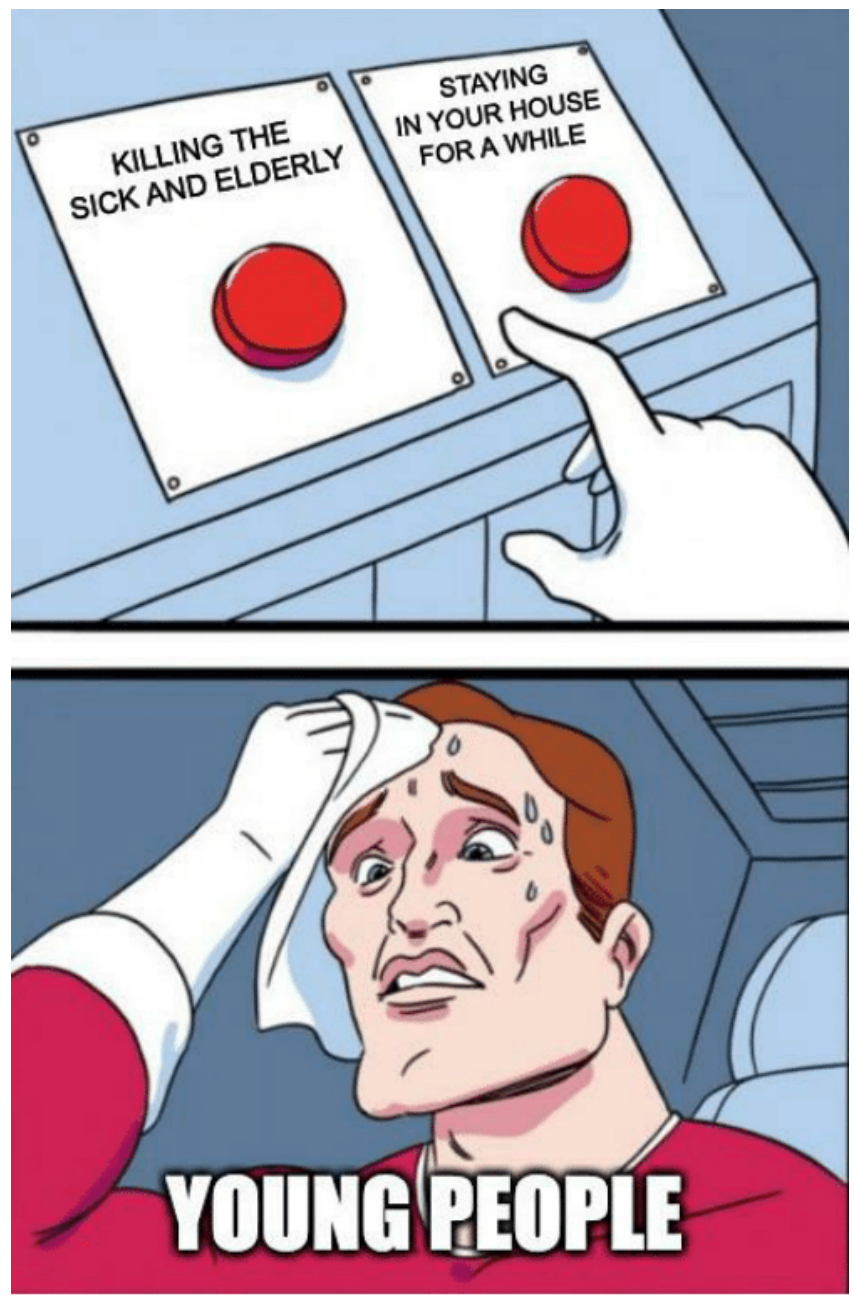

For the love of God, please stay home!

Figure 19. For the love of God, please stay home! [u/Mobius_Dick, 2020].

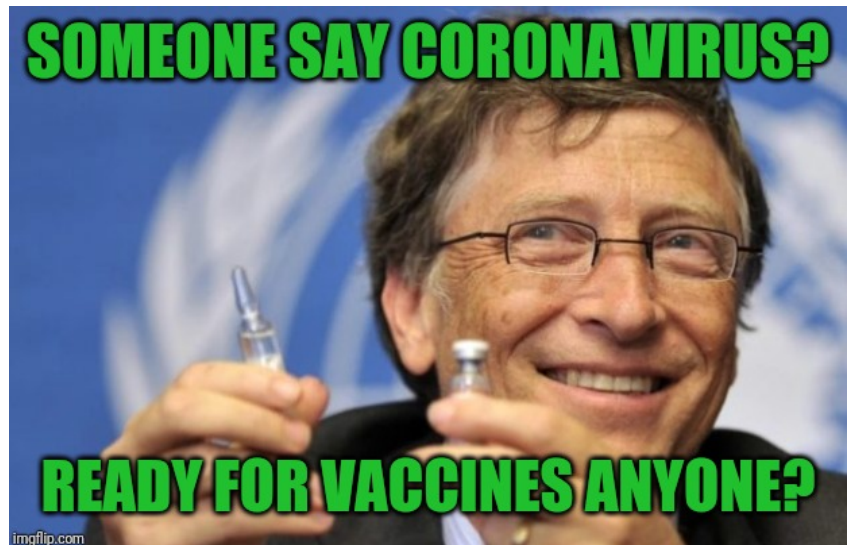

Figure 20. Perfectly profitable pandemic? Patented. Nothing like a Good Crisis [HILLARrests, 2020]. 
different text, all in the name of the overarching conspiracy theories (see Figure 21 and Figure 22 as examples).

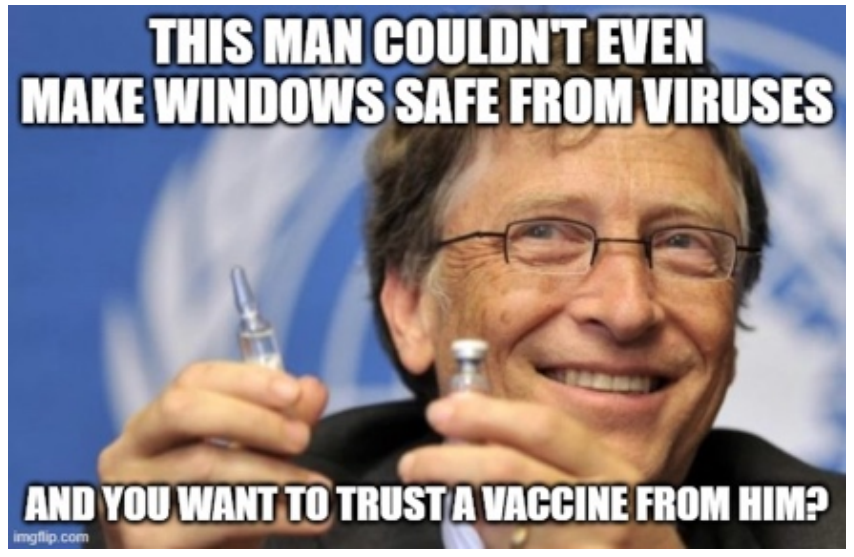

Figure 21. Bill Gates loves Vaccines [Killercod, 2020].

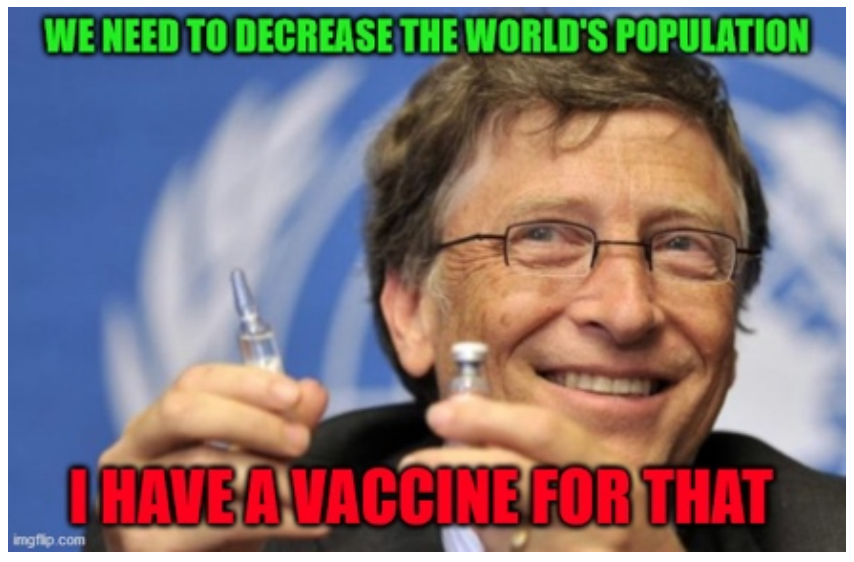

Figure 22. Bill Gates loves Vaccines [Imgflip, 2020a].

The pressure on research scientists is immense particularly when anti-vaxxers exercise their voice in the rhetorical arena. In figure 23 the punchline of the meme suggests that scientists are untrustworthy, and vaccines are dangerous but the tone of the meme and also the interpretation of the semiotic resources might depend on who shares the meme. If an anti-vaxxer shared this meme it could be interpreted in the literal sense that vaccines are dangerous and cause autism and scientists are responsible. If someone who finds anti-vaxxers ridiculous posts this to their social media with a rolling eyes emoji, then the tone shifts to one of sarcasm. The context under which a meme is shared, regardless of who creates it, impacts the production of meaning. Most people understand that research scientists around the world are working hard to find a vaccine even if some meme creators make light of their work (see Figure 24).

The truth is that everyday folks should make themselves a drink and relax and allow the experts to do their jobs. Sooner or later the world will emerge from this crisis because of efforts made by the scientific community. When that new normal begins, perhaps a non-partisan appreciation of each other and of our leaders and scientists will emerge as well. For now, 2 parts rum, 1 part crème de menthe... 


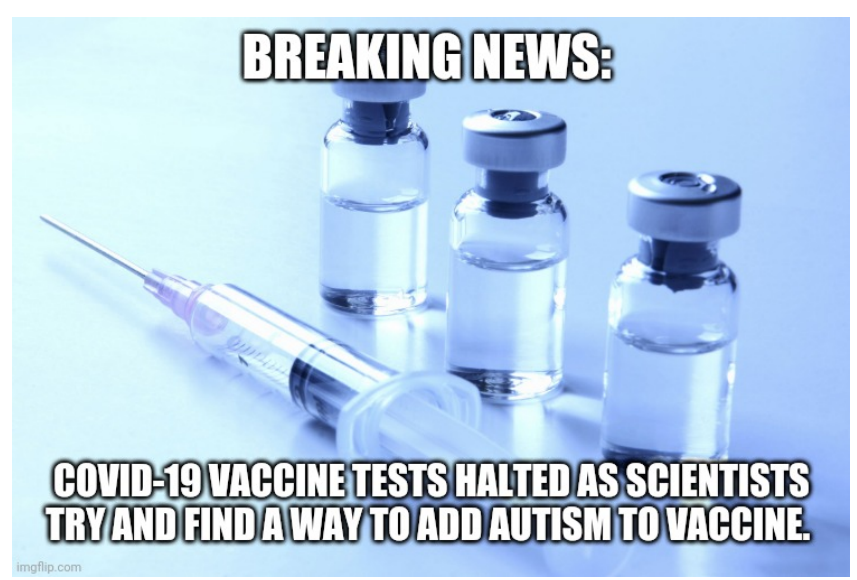

Figure 23. Vaccine [Imgflip, 2020b].

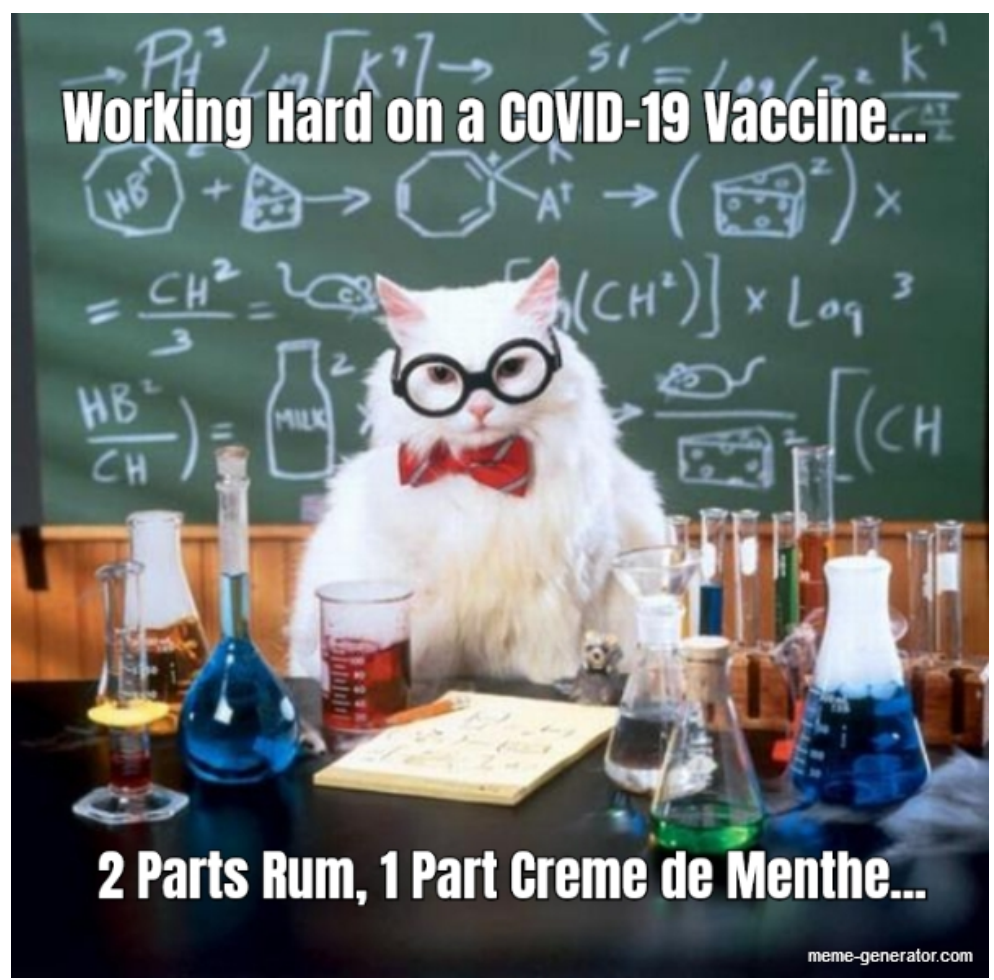

Figure 24. Working Hard on a COVID-19 Vaccine... [Meme Generator, 2020].

Conclusion

Crisis memes are unique communicative artifacts at play in the public discourse during the cycle of a crisis. They are loaded with meaning-making potential that is tied to the social and cultural implications that surface during a crisis. This paper looked at how rhetorical arena theory and multimodality can be used as a basis for detailed analysis of crisis memes. Meme creators design crisis memes from the semiotic resources they source from communicative occurrences between actors inside the rhetorical arena. Crisis memes make social commentary about the experience of living through a crisis like the COVID-19 pandemic. This commentary takes many forms like incredulousness or judgement but only makes sense when related back to the discourse community of the rhetorical arena. A multimodal approach was used to look at the complexity of crisis memes and to determine how the meme modes produce meaning, sometimes in harmony and 
Appendix A. Memes, modes and potential meanings other times in discord. COVID-19 crisis memes demonstrate attitudes about actors and stakeholders that emerge in the arena inclusive of citizens, government agencies and officials, health and science experts, among others. A limitation of this paper is its use of only a few meme types. Future studies may consider looking at other forms of memes like video memes or stacked image memes. The study of memes as cultural artifacts is certainly germane and salient in the area of communication studies. Understanding crisis memes may be helpful in practice as well since organizations in crisis may find themselves working to respond to memes that attack their image, product, or effectiveness during a crisis response. At the time of this writing, the COVID-19 crisis is still in the crisis stage, but the hope is that soon everyone will be moving towards a post-crisis life with what will inevitably be a new normal.

\begin{tabular}{|c|c|c|}
\hline $\begin{array}{c}\text { Meme Thumbnail } \\
\text { Number } \\
\text { Type }\end{array}$ & Modes & $\begin{array}{l}\text { Potential Meanings } \\
\text { (not exhaustive) }\end{array}$ \\
\hline 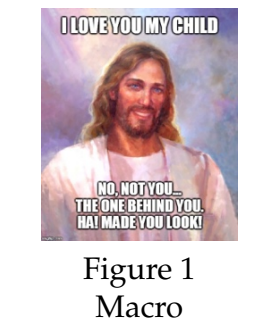 & $\begin{array}{l}\text { 1. Image of Jesus (dominant) } \\
\text { 2. Text with set-up/punchline }\end{array}$ & $\begin{array}{l}\text { Humorous, Jesus loves every- } \\
\text { one...but you, childhood games }\end{array}$ \\
\hline $\begin{array}{c}\text { Figure } 5 \\
\text { Macro }\end{array}$ & $\begin{array}{l}\text { 1. The COVID-19 pandemic } \\
\text { crisis (dominant mode) } \\
\text { 2. Image with arm and disin- } \\
\text { fectant } \\
\text { 3. Text }\end{array}$ & $\begin{array}{l}\text { Sarcastic, indictment of Trump's } \\
\text { suggestion, attack on Trump's intel- } \\
\text { ligence }\end{array}$ \\
\hline 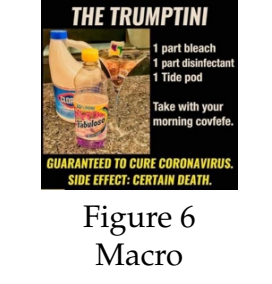 & $\begin{array}{l}\text { 1. The COVID-19 pandemic } \\
\text { crisis (dominant mode) } \\
\text { 2. Image } \\
\text { 3. Text }\end{array}$ & $\begin{array}{l}\text { Sarcastic, indictment of Trump's } \\
\text { suggestion, attack on Trump's in- } \\
\text { telligence, play on bars/restaurants } \\
\text { being closed (bartender work form } \\
\text { home) }\end{array}$ \\
\hline $\begin{array}{l}\text { Figure } 8 \\
\text { Shop }\end{array}$ & $\begin{array}{l}\text { 1. The COVID-19 pandemic } \\
\text { crisis (dominant mode) } \\
\text { 2. Image (photoshopped) }\end{array}$ & $\begin{array}{l}\text { Social distancing, encouraging } \\
\text { people to adopt good habits, } \\
\text { humorous }\end{array}$ \\
\hline
\end{tabular}

Continued on the next page. 
Table 1. Continued from the previous page.

\begin{tabular}{|c|c|c|}
\hline $\begin{array}{l}\text { Meme Thumbnail } \\
\text { Number } \\
\text { Type }\end{array}$ & Modes & $\begin{array}{l}\text { Potential Meanings } \\
\text { (not exhaustive) }\end{array}$ \\
\hline $\begin{array}{c}\text { Figure } 9 \\
\text { Shop }\end{array}$ & $\begin{array}{l}\text { 1. The COVID-19 pandemic } \\
\text { crisis (dominant mode) } \\
\text { 2. Image (photoshopped) }\end{array}$ & $\begin{array}{l}\text { Social distancing, mask wearing, } \\
\text { encouraging people to adopt good } \\
\text { habits, humorous }\end{array}$ \\
\hline 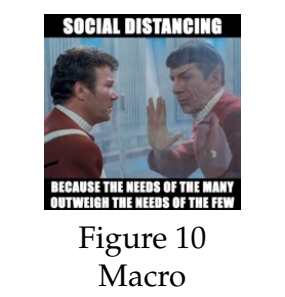 & $\begin{array}{l}\text { 1. The COVID-19 pandemic } \\
\text { crisis (dominant mode) } \\
\text { 2. Image of Star Trek } \\
\text { 3. Text }\end{array}$ & $\begin{array}{l}\text { Sacrificing for the greater good, } \\
\text { Vulcan salute as alternative to } \\
\text { handshake, } \\
\text { Separation from loved ones }\end{array}$ \\
\hline $\begin{array}{l}\text { Figure } 11 \\
\text { Macro }\end{array}$ & $\begin{array}{l}\text { 1. The COVID-19 pandemic } \\
\text { crisis (dominant mode) } \\
\text { 2. Image } \\
\text { 3. Text }\end{array}$ & $\begin{array}{l}\text { Judgment on people not following } \\
\text { rules, humans are the real animals, } \\
\text { new normal at grocery stores, hu- } \\
\text { morous }\end{array}$ \\
\hline 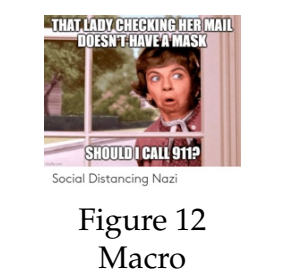 & $\begin{array}{l}\text { 1. The COVID-19 pandemic } \\
\text { crisis (dominant mode) } \\
\text { 2. Image } \\
\text { 3. Text }\end{array}$ & $\begin{array}{l}\text { People do not follow rules, people } \\
\text { cannot mind their own business, } \\
\text { government encourages reporting } \\
\text { on fellow citizens }\end{array}$ \\
\hline 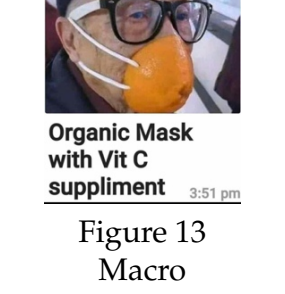 & $\begin{array}{l}\text { 1. The COVID-19 pandemic } \\
\text { crisis (dominant mode) } \\
\text { 2. Image } \\
\text { 3. Text }\end{array}$ & $\begin{array}{l}\text { DIY masks, government unpre- } \\
\text { pared/shortages, organic is better } \\
\text { than synthetic, humorous }\end{array}$ \\
\hline $\begin{array}{l}\text { Product package said } \\
\text { FAcEc' mask } \\
\text { Figure } 14 \\
\text { Macro }\end{array}$ & $\begin{array}{l}\text { 1. The COVID-19 pandemic } \\
\text { crisis (dominant mode) } \\
\text { 2. Image } \\
\text { 3. Text }\end{array}$ & $\begin{array}{l}\text { People do not know how to } \\
\text { properly use masks, government } \\
\text { leaves citizens without proper } \\
\text { advice/instruction, humorous }\end{array}$ \\
\hline
\end{tabular}

Continued on the next page. 
Table 1. Continued from the previous page.

\begin{tabular}{|c|c|c|}
\hline $\begin{array}{l}\text { Meme Thumbnail } \\
\text { Number } \\
\text { Type }\end{array}$ & Modes & $\begin{array}{l}\text { Potential Meanings } \\
\text { (not exhaustive) }\end{array}$ \\
\hline 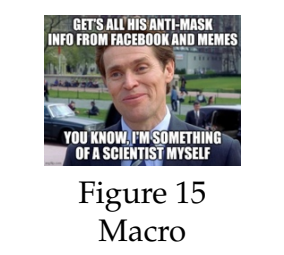 & $\begin{array}{l}\text { 1. The COVID-19 pandemic } \\
\text { crisis (dominant mode) } \\
\text { 2. Image (Defoe as comic book } \\
\text { villain) } \\
\text { 3. Text }\end{array}$ & $\begin{array}{l}\text { Anti-maskers are idiots, people } \\
\text { should listen to scientists, stop get- } \\
\text { ting (mis)information from social } \\
\text { media, humorous }\end{array}$ \\
\hline 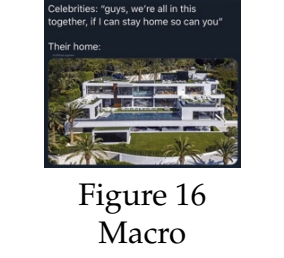 & $\begin{array}{l}\text { 1. The COVID-19 pandemic } \\
\text { crisis (dominant mode) } \\
\text { 2. Image } \\
\text { 3. Text }\end{array}$ & $\begin{array}{l}\text { Pandemic does not affect people the } \\
\text { same in all classes, privilege shows } \\
\text { from celebrities and the rich, sar- } \\
\text { castic }\end{array}$ \\
\hline $\begin{array}{l}\text { Figure } 17 \\
\text { Macro }\end{array}$ & $\begin{array}{l}\text { 1. The COVID-19 pandemic } \\
\text { crisis (dominant mode) } \\
\text { 2. Image } \\
\text { 3. Text }\end{array}$ & $\begin{array}{l}\text { Staying home is not that hard, this } \\
\text { is not war, stop complaining, sar- } \\
\text { castic, humorous }\end{array}$ \\
\hline $\begin{array}{l}\text { Figure } 18 \\
\text { Macro }\end{array}$ & $\begin{array}{l}\text { 1. The COVID-19 pandemic } \\
\text { crisis (dominant mode) } \\
\text { 2. Image } \\
\text { 3. Text }\end{array}$ & $\begin{array}{l}\text { There is a healthcare professional } \\
\text { shortage, stay home or risk getting } \\
\text { sick and not being cared for, humor- } \\
\text { ous }\end{array}$ \\
\hline $\begin{array}{l}\text { Forthelove of God, pease stay } \\
\text { home! } \\
\text { Figure } 19 \\
\text { Macro Shop Hybrid }\end{array}$ & $\begin{array}{l}\text { 1. The COVID-19 pandemic } \\
\text { crisis (dominant mode) } \\
\text { 2. Image (photoshopped) } \\
\text { 3. Text }\end{array}$ & $\begin{array}{l}\text { Stay home or kill family/neighbors, } \\
\text { tough choice between a party life- } \\
\text { style and a coffin, humorous }\end{array}$ \\
\hline $\begin{array}{l}\text { Figure } 20 \\
\text { Macro }\end{array}$ & $\begin{array}{l}\text { 1. The COVID-19 pandemic } \\
\text { crisis (dominant mode) } \\
\text { 2. Image } \\
\text { 3. Text }\end{array}$ & $\begin{array}{l}\text { Bill Gates conspiracy theories, } \\
\text { Gates wants to take over the world } \\
\text { and is untrustworthy, humorous }\end{array}$ \\
\hline
\end{tabular}

Continued on the next page. 
Table 1. Continued from the previous page.

\begin{tabular}{|c|c|c|}
\hline $\begin{array}{c}\text { Meme Thumbnail } \\
\text { Number } \\
\text { Type }\end{array}$ & Modes & $\begin{array}{c}\text { Potential Meanings } \\
\text { (not exhaustive) }\end{array}$ \\
\hline $\begin{array}{l}\text { Figure } 21 \\
\text { Macro }\end{array}$ & $\begin{array}{l}\text { 1. The COVID-19 pandemic } \\
\text { crisis (dominant mode) } \\
\text { 2. Image } \\
\text { 3. Text }\end{array}$ & $\begin{array}{l}\text { Bill Gates conspiracy theories, } \\
\text { Gates wants to take over the world } \\
\text { and is untrustworthy, humorous }\end{array}$ \\
\hline $\begin{array}{l}\text { Figure } 22 \\
\text { Macro }\end{array}$ & $\begin{array}{l}\text { 1. The COVID-19 pandemic } \\
\text { crisis (dominant mode) } \\
\text { 2. Image } \\
\text { 3. Text }\end{array}$ & $\begin{array}{l}\text { Bill Gates conspiracy theories, } \\
\text { Gates wants to take over the world } \\
\text { and is untrustworthy, humorous }\end{array}$ \\
\hline 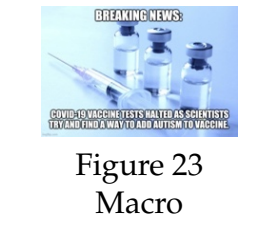 & $\begin{array}{l}\text { 1. The COVID-19 pandemic } \\
\text { crisis (dominant mode) } \\
\text { 2. Image } \\
\text { 3. Text }\end{array}$ & $\begin{array}{l}\text { Cannot trust scientists, anti- } \\
\text { vaxxers, sarcastic }\end{array}$ \\
\hline 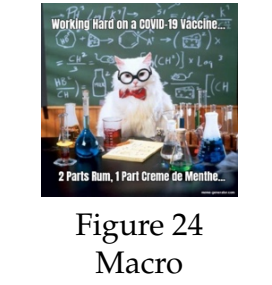 & $\begin{array}{l}\text { 1. The COVID-19 pandemic } \\
\text { crisis (dominant mode) } \\
\text { 2. Image } \\
\text { 3. Text }\end{array}$ & $\begin{array}{l}\text { Scientist are hard at work, people } \\
\text { should have a drink and relax, bar- } \\
\text { tenders are working from home, } \\
\text { humorous }\end{array}$ \\
\hline
\end{tabular}

\section{References}

Aaaadam [@official.agnew] (24th March 2020). Celebrities: we're all in this together. [Meme]. URL: https://www . instagram.com/p/B-Hx39shLDBKmVtppGZgzJT1E6Ch YGzagNc9cw0/.

Aitken, P. (26th April 2020). 'States see spike in poison control calls following Trump's comments on injecting disinfectant'. Fox News.

URL: https://www . foxnews. com/us/states-spike-poison-control-calls. Apple Corps (2020). Abbey road.

URL: https://www . thebeatles . com/album/abbey-road.

Art by EQ (16th March 2020). They had a fine eye for detail. [Twitter post]. URL: https ://twitter.com/art_by_eq/status/1239544250586497025/photo/1.

Breuninger, K. (20th July 2020). 'Trump says face masks are 'patriotic' after months of largely resisting wearing one'. CNBC.

URL: https://www . cnbc.com/2020/07/20/trump-says-coronavirus-masks-ar e-patriotic-after-months-of-largely-resisting-wearing-one.html.

Business Today (7th March 2020). Coronavirus: why Xi Jinping did not wear the safer N95 mask to hospital. URL: https: //www. businesstoday. in/current/world/cor onavirus-why-xi-jinping-did-not-wear-the-safer-n95-mask-to-hospital /story/396036.html.

Centers for Disease Control and Prevention (6th July 2020a). How to make masks. URL: https://www.cdc.gov/coronavirus/2019-ncov/prevent-getting-sick /how-to-make-cloth-face-covering.html. 
Centers for Disease Control and Prevention (24th August 2020b). Limiting workplace violence associated with COVID-19 prevention policies in retail and service businesses. URL: https://www.cdc.gov/coronavirus/2019-ncov/community/organizatio ns/business-employers/limit-workplace-violence.html.

Chambers, M. (2nd April 2020). 'Germans snitch on neighbours flouting virus rules, in echo of the Stasi past'. Reuters. URL: https://www. reuters . com/article/ushealth-coronavirus-germany-denunciati/germans-snitch-on-neighboursflouting-virus-rules-in-echo-of-the-\%20stasi-past-idUSKBN21K2PB. cheezburger.com (2020). A polite cat. URL: https://cheezburger.com/9471297536/a-polite-cat.

Clark, D. (23rd April 2020). 'Trump suggests 'injection' of disinfectant to beat coronavirus and 'clean' the lungs'. NBC News.

URL: https://www . today . com/news/trump-suggests-injection-disinfectan t-beat-coronavirus-clean-lungs-t179814.

Clark, T. (6th March 2020). 'Pandemic movie 'Contagion' is surging in popularity due to the coronavirus and has hit the no. 7 spot on iTunes'. Business Insider. URL: https://www . businessinsider . com/coronavirus-contagion-movie-issurging-in-piracy-rentals-on-itunes-2020-3.

Coombs, T. W. (2010). 'Perimeters of crisis communication'. In: The handbook of crisis communication. Ed. by T. W. Coombs and S. J. Holladay. Malden, MA, U.S.A.: Wiley Blackwell, pp. 17-53.

Cooper, G. F. (10th March 2020). 'Spock's Vulcan salute as greeting reportedly spreads to Congress'. CNET. URL: https://www. cnet.com/news/spocks-vulcan -salute-as-greeting-reportedly-spreads-to-congress/.

Cramer, M. and Sheikh, K. (29th February 2020). 'Surgeon general urges the public to stop buying face masks'. The New York Times. URL: https : / www . nytimes . com /2020/02/29/health/coronavirus-n95-face-masks.html.

De Avila, J. and Chen, T. (31st March 2020). 'To fight Coronavirus, states call on retired medical staff and new graduates'. The Wall Street.

URL: https://www.wsj .com/articles/to-fight-coronavirus-states-call-o n-retired-medical-staff-and-new-graduates-11585647003.

Dockrill, P. (10th August 2020). 'Simple new experiment reveals which face masks are best at blocking droplets'. Science Alert.

URL: https://www.sciencealert.com/simple-low-cost-experiment-reveals -which-face-masks-are-best-at-blocking-droplets.

Foran, C., Fox, L. and Herb, J. (10th March 2020). 'Lawmakers advised to give 'Star Trek' greeting to avoid contact as Hill prepares for coronavirus'. CNN.

URL: https://www.cnn.com/2020/03/10/politics/coronavirus-congress-pr ecautions-greeting/index.html.

Frandsen, F. and Johansen, W. (2010). 'Crisis communication, complexity and the cartoon affair: a case study'. In: The handbook of crisis communication. Ed. by T. W. Coombs and S. J. Holladay. Malden, MA, U.S.A.: Wiley-Blackwell, pp. 425-448. https://doi.org/10.1002/9781444314885.ch21.

Genius (2020). American pie lyrics. URL: https://genius . com/Don-mclean-american-pie-lyrics.

Grundlingh, L. (2018). 'Memes as speech acts'. Social Semiotics 28 (2), pp. 147-168. https://doi.org/10.1080/10350330.2017.1303020.

Grynbaum, M. M. (24th April 2020). “Don't try this at home': even 'Fox \& Friends' balked at Trump's advice'. The New York Times. URL: https: //www . nytimes . com /2020/04/24/business/media/virus-fox-trump-disinfectant.html. 
Heath, R. L. (2010). 'Introduction crisis communication: defining the beast and de-marginalizing key publics'. In: The handbook of crisis communication. Ed. by T. W. Coombs and S. J. Holladay. Malden, MA, U.S.A.: Wiley Blackwell, pp. 1-13.

HILL-ARrests (2020). Perfectly profitable pandemic? Patented. Nothing like a good crisis. URL: https://imgflip.com/tag/bill+gates+loves+vaccines.

Igielnik, R. (23rd June 2020). 'Most Americans say they regularly wore masks in stores in the past month; fewer see others doing it'. Pew Research Center.

URL: https://www . pewresearch.org/fact-tank/2020/06/23/most-americans - say-they-\%20regularly-wore-a-mask-in-stores-in-the-past-month-fewe r-see-others-doing-it/.

Imgflip (2020a). Bill Gates loves vaccines. URL: https : / imgflip. com/i/3veyw9.

- (2020b). Vaccine. URL: https://imgflip.com/i/3wkilv.

Jewitt, C. (2013). 'Multimodal methods for researching digital technologies'. In: The SAGE handbook of digital technology research. Ed. by S. Price, C. Jewitt and B. Brown. London, U.K.: SAGE Publications Ltd, pp. 250-265. https://doi.org/10.4135/9781446282229.n18.

Katella, K. (7th April 2020). ‘Our new COVID-19 vocabulary — what does it all mean?' Yale Medicine.

URL: https://www . yalemedicine org/stories/covid-19-glossary/.

Killercod (2020). Bill Gates loves vaccines. URL: https://imgflip.com/tag/bill+gates+loves+vaccines.

Kress, G. (n.d.). 'Multimodal discourse analysis'. In: The Routledge handbook of discourse analysis. Ed. by J. P. Gee and M. Handford. New York, NY, U.S.A.: Routledge, pp. 35-50. https://doi.org/10.4324/9780203809068.ch3.

Lapachinsky, S. (2020). Stay home unless you want to be intubated by a gynecologist. URL: https://www . pinterest.com/pin/304133781089359328.

Luoma-aho, V. and Vos, M. (2010). 'Towards a more dynamic stakeholder model: acknowledging multiple issue arenas'. Corporate Communications: An International Journal 15 (3), pp. 315-331. https://doi.org/10.1108/13563281011068159.

makeameme.org (2020). Your grandparents were called to war meme. URL: https ://makeameme .org/meme/your-grandparents-were.

Martoccio, A. (3rd February 2019). 'Flashback: Don McLean plays a stirring 'American Pie' in 1972'. Rolling Stone. URL: https://www.rollingstone .com/mu sic/music-news/don-mclean-american-pie-live-day-music-died-786825/.

MassGeneralHospital (25th March 2020). How to tie a surgical mask. [YouTube video]. URL: https : //www . youtube. com/watch?v=Ck0EtEdp8vw.

me.me (2020). Social distancing Nazi meme. URL: https://me.me/i/social-distanc ing-nazi-24e4f5afc9fe42a0ac72f3703bb0eee1.

Meme Generator (2020). Working hard on a COVID-19 vaccine... URL: https://meme-generator . com/mememe/working-hard-on-a-covid-19-va ccine-2-parts-rum-1-part-cr/.

Merriam-Webster (2020). Arena. URL: https://www.merriam-webster.com/dictionary/arena (visited on 25th April 2020).

Milner, R. M. (2012). 'The world made meme: discourse and identity in participatory media'. Doctoral dissertation. Lawrence, KS, U.S.A.: University of Kansas. URL: http://hdl. handle.net/1808/10256.

National Institutes of Health (2020). Vitamin C. Fact sheet for health professionals. URL: https://ods.od.nih.gov/factsheets/VitaminC-HealthProfessional/. 
Noack, R. (10th February 2020). 'Mask-clad Xi Jinping emerges from conspicuous absence to visit coronavirus "front line". The Seattle Times.

URL: https://www. seattletimes . com/nation-world/mask-clad-xi-jinpingemerges-from-conspicuous-absence-to-visit-coronavirus-front-line/.

Owoseje, T. (23rd March 2020). 'Coronavirus is 'the great equalizer', Madonna tells fans from her bathtub'. CNN. URL: https://www. cnn. com/2020/03/23/enterta inment/madonna-coronavirus-video-intl-scli/index.html.

Patton, M. Q. (2014). Qualitative research \& evaluation methods: integrating theory and practice. Los Angeles, CA, U.S.A.: SAGE Publications.

Reckitt Benckiser (2020). Improper use of disinfectants. URL: https : //www . rb . com/med $\mathrm{ia/news/2020/april/improper-use-of-disinfectants/.}$

Reddit (2020). Anti-maskers. URL: https://www.reddit.com/r/CoronavirusMemes/c omments/hrw8co/antimaskers/.

Renown Health (2020). Renown health nurses demonstrate how to wear protective masks. [YouTube video]. URL: https: //www . youtube. com/watch?v=uSldNR80xrM.

Rosy [@rose_ko1] (6th April 2020). Innovative masks. [Twitter post]. URL: https://twitter.com/rose_k01/status/1247165995501813765.

Ruiz, M. (18th April 2020). 'De Blasio: New Yorkers can report social distancing violations by texting photos to authorities'. Fox News.

URL: https://www . foxnews . com/us/de-blasio-new-yorkers-report-socialdistancing-violations-text.

Rupar, A. (3rd March 2020). ‘Trump's ignorance was on public display during coronavirus meeting with pharmaceutical execs'. Vox.

URL: https://www. vox.com/2020/3/3/21162772/trump-coronavirus-meeting -pharmaceutical-executives-white-house-covid-19.

Sallin (Producer), R. and Meyer (Director), N. (1982). Star Trek II: the wrath of Khan. [Motion picture]. U.S.A.

Shifman, L. (2012). 'An anatomy of a YouTube meme'. New Media \& Society 14 (2), pp. 187-203. https://doi.org/10.1177/1461444811412160.

shutupandtakemymoney.com (2020). Injecting disinfectant Trump Lysol Clorox meme. URL: http://www . shutupandtakemymoney . com/injecting-disinfectant-trum p-lysol-clorox-meme/.

Siefkes, M. (2015). 'How semiotic modes work together in multimodal texts: defining and representing intermodal relations'. 10plus1 - Living Linguistics 1, pp. 113-131. URL: http://10plus1journal.com/?page_id=280.

somethingtolaughat.com (23rd April 2020). The Trumptini Clorox drink meme. URL: ht tps://somethingtolaughat.com/video/the-trumptini-clorox-drink-meme/.

Stanley, B. (16th March 2020). Well done, lads. [Twitter post]. URL: https://twitter.com/BDStanley/status/1239464963976105985.

Star Trek Discovery Memes (15th March 2020). Star Trek social distancing meme. URL: https://www. facebook. com/stdmemes/photos/a.736609206531549/1335 453719980425.

Stengel, R. (28th June 2010). 'Inside the red border'. Time. URL: http: // content . tim e.com/time/magazine/article/0,9171,1997446,00.html.

Stewart, E. (7th August 2020). 'Anti-maskers explain themselves'. Vox. URL: https://www.vox.com/the-goods/2020/8/7/21357400/anti-mask-prote st-rallies-donald-trump-covid-19.

Strauss, A. (1978). 'A social worlds perspective'. Studies in Symbolic Interaction 1, pp. 119-128. 
The Funny Beaver (2020). Funny face masks memes that are unmasking faster than people can buy masks.

URL: https://thefunnybeaver .com/corona-virus-memes-face-mask-meme/.

The White House (23rd April 2020). Remarks by President Trump, Vice President Pence and members of the Coronavirus task force in press briefing. URL: https://www . white house.gov/briefings-statements/remarks-president-trump-vice-preside nt-pence-members-coronavirus-task-force-press-briefing-31/.

Theoharis, L. (22nd April 2020). 'Inequality and poverty were destroying America well before COVID-19'. The Nation.

URL: https://www . thenation.com/article/society/inequality-and-povert y-were-destroying-america-well-before-covid-19/.

TikiHut (2020). Irreverent Jesus, I love you. URL: https: //imgflip.com/i/39yarm.

$\mathrm{u}$ /Mobius_Dick (2020). For the love of God, please stay home! URL: https : / / www . reddi t.com/r/memes/comments/flomj8/for_the_love_of_god_please_stay_home/.

United States Environmental Protection Agency (23rd April 2020). EPA provides critical information to the American public about safe disinfectant use.

URL: https://www.epa.gov/newsreleases/epa-provides-critical-informat ion-american-public-about-safe-disinfectant-use.

Van Leeuwen, T. (2005). Introducing social semiotics. New York, U.S.A.: Routledge. Wakabayashi, D., Alba, D. and Tracy, M. (17th April 2020). 'Bill Gates, at odds with Trump on virus, becomes a right-wing target'. The New York Times.

URL: https://www .nytimes . com/2020/04/17/technology/bill-gates-virusconspiracy-theories.html.

White-Farnham, J. (2019). 'Resisting "Let's Eat Grandma": the rhetorical potential of grammar memes'. Computers and Composition 52, pp. 210-221. https://doi.org/10.1016/j.compcom.2019.02.001.

Wiggins, B. E. and Bowers, G. B. (2015). 'Memes as genre: a structurational analysis of the memescape'. New Media \& Society 17 (11), pp. 1886-1906.

https://doi.org/10.1177/1461444814535194.

Author

Rick Pulos is a doctoral student in Communication Studies at Regent University. He is a published playwright, theatre producer, artist, performer and educator and has performed all over the United States in venues such as the Nuyorican Poets Cafe, the Tilles Center for the Performing Arts and Highways Performance Space. He studied theatre and film at Yale University as well as storyboard design and animation under the guidance of Academy Award winner Faith Hubley. He attended the School of Cinematic Arts at the University of Southern California where he studied with various experimental and commercial artists and directors. $\mathrm{He}$ is a native Californian transplanted to New York City.

E-mail: rickpulos@yahoo.com.

\section{How to cite}

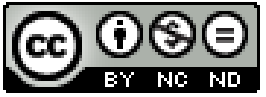

Pulos, R. (2020). 'COVID-19 crisis memes, rhetorical arena theory and multimodality'. JCOM 19 (07), A01. https:/ / doi.org/10.22323/2.19070201. 